\title{
Determinants of Sensitivity to Radiotherapy in Endometrial Cancer
}

\author{
Maria Alba Sorolla ${ }^{1,+}$, Eva Parisi ${ }^{1,+}$ and Anabel Sorolla $2, *$ (D) \\ 1 Research Group of Cancer Biomarkers, Biomedical Research Institute (IRB Lleida), 25198 Lleida, Spain; \\ msorolla@irblleida.cat (M.A.S.); eparisi@irblleida.cat (E.P.) \\ 2 Harry Perkins Institute of Medical Research, QEII Medical Centre, Nedlands and Centre for Medical \\ Research, The University of Western Australia, Crawley, Western Australia 6009, Australia \\ * Correspondence: anabel.sorollabardaji@perkins.uwa.edu.au; Tel.: +61-8-6151-0991 \\ + These authors contributed equally to the work.
}

Received: 18 June 2020; Accepted: 13 July 2020; Published: 15 July 2020

\begin{abstract}
Radiotherapy is one of the cornerstone treatments for endometrial cancer and has successfully diminished the risk of local recurrences after surgery. However, a considerable percentage of patients suffers tumor relapse due to radioresistance mechanisms. Knowledge about the molecular determinants that confer radioresistance or radiosensitivity in endometrial cancer is still partial, as opposed to other cancers. In this review, we have highlighted different central cellular signaling pathways and processes that are known to modulate response to radiotherapy in endometrial cancer such as PI3K/AKT, MAPK and NF-KB pathways, growth factor receptor signaling, DNA damage repair mechanisms and the immune system. Moreover, we have listed different clinical trials employing targeted therapies against some of the aforementioned signaling pathways and members with radiotherapy. Finally, we have identified the latest advances in radiotherapy that have started being utilized in endometrial cancer, which include modern radiotherapy and radiogenomics. New molecular and genetic studies in association with the analysis of radiation responses in endometrial cancer will assist clinicians in taking suitable decisions for each individual patient and pave the path for personalized radiotherapy.
\end{abstract}

Keywords: endometrial cancer; radiotherapy; signaling pathways; clinical trials; radiogenomics

\section{Introduction}

Endometrial cancer (EC) was the second most frequent gynecologic malignancy and the sixth most diagnosed cancer in women worldwide in 2018 [1]. Around 75\% of ECs are confined in the uterine corpus and 15-20\% recur after primary surgery. Of them, approximately $1 / 3$ recurs in the vagina and pelvic regions and 2/3 at distant sites [2]. Patients with localized EC present a 5-year survival rate of $95 \%$ and such a rate decreases to $16 \%$ with the presence of distant metastasis [3].

The vast majority of ECs are adenocarcinomas. They have been classically divided in two different histological types: type 1 or endometrioid carcinomas, and type 2, which include uterine serous carcinomas and clear cell carcinomas [4]. Type 1 carcinomas account for $70-80 \%$ of all ECs. They are low-grade moderate to well differentiated tumors and have good prognosis. In contrast, type 2 tumors, which account for 10-20\% of all ECs, are high-grade poorly differentiated tumors and have poor prognosis due to their high risk of recurrence and metastasis [4]. The genomic sequencing initiative 'The Cancer Genome Atlas' has allowed the identification of four different molecular subtypes of ECs: polymerase $\varepsilon$ exonuclease (POLE) ultramutated, microsatellite instability (MSI) hypermutated, copy-number low and copy-number high [5]. When comparing with the traditional classification, the authors found that $40 \%$ of the endometrioid tumors are MSI while MSI is present in only $2 \%$ of serous tumors. 
Pathological stage plays a crucial role in treatment decision of ECs. Current forms of radiotherapy (RT) to treat ECs consist of high-energy external beam radiation therapy (EBRT) and brachytherapy (BT), the placement of radioactive isotopes into the vagina. Although RT has been successful in preventing local recurrences after surgery, there is still risk of RT failure with patterns of local and distant recurrences; 5 -year probability of distant recurrences of $29.1 \%$ in patients with high-risk EC treated with RT alone has been reported [6]. Therefore, research focused on finding the molecular mechanisms that determine the acquisition of resistance and a lack of sensitivity to RT and consequent cancer relapse in EC is essential.

In the current work, we have reviewed the molecular determinants of RT sensitivity in EC, which include the status of the cancer survival pathways phosphatidylinositol 3-kinase (PI3K)/PTEN/protein kinase B (AKT)/mammalian target of rapamycin (mTOR), nuclear factor-kappa B (NF- $\mathrm{KB}$ ) and mitogen-activated protein kinase (MAPK) pathway; oncoproteins such as tyrosine kinase receptors and growth hormone; proteins involved in DNA repair mechanisms and the immune system. Additionally, we have listed the current clinical trials studying the effects of targeted therapies directed to the above cellular mechanisms with RT in EC. Furthermore, we have provided an overview of the latest cutting-edge advances in RT that have the potential to lead the development of targeted RT for EC.

\section{Current State of the Art in Treatment of Endometrial Cancer}

The most established treatment options for EC are surgery, RT and standard chemotherapy. There are also two approved targeted therapies for clinical use, which are megestrol acetate [7] and the combination of pembrolizumab and lenvatinib [8].

The selection of treatment is done after rigorous examination, which considers the following factors: family history, patients' performance status, diagnostic features, clinical staging and risk assessment. Clinical staging, I-IV must follow The International Federation of Gynecology and Obstetrics (FIGO) classification, first described in 1988 [9] and revised later in 2009 [10]. Risk assessment is based on clinicopathological prognostic factors, which include age, FIGO stage, depth of myometrial invasion, tumor differentiation grade, tumor type (endometrioid versus serous and clear cell) and lymphovascular space invasion.

The clinical practice guidelines of the European Society of Medical Oncology (ESMO) for the management of EC patients constitutes an important tool for the application of the suitable treatment [11]. According to ESMO, early-stage low-risk EC patients should be managed with surgery alone, in particular total hysterectomy and bilateral salpingo-oophorectomy. Intermediate-risk EC could be considered for lymphadenectomy for staging, and adjuvant BT is recommended for treatment. Intermediate-high risk EC patients should be treated with adjuvant BT or EBRT, depending on the nodal status and histological grade. High-risk EC patients could be recommended for lymphadenectomy and adjuvant EBRT, combined with chemotherapy under specific circumstances. This in agreement with the results of the GOG-249 trial [12], which demonstrates that RT alone remains an effective, well-tolerated and appropriate adjuvant treatment in high-intermediate and high-risk early-stage EC. Stage II patients can undergo radical hysterectomy. Lymphadenectomy is recommended to guide staging and adjuvant therapy. In this stage, adjuvant therapy will include vaginal BT, EBRT and BT boosts. They can be combined with chemotherapy, depending on nodal staging and tumor grade. In stage III patients, surgery will include complete macroscopic cytoreduction. Adjuvant chemotherapy plus EBRT will be considered in IIIA, IIIB and IIIC1 stages or plus extended field EBRT in the IIIC2 stage. In high-risk non-endometrioid cancer, the adjuvant options are vaginal BT or EBRT plus chemotherapy depending on stage and histology. In these cases, chemotherapy is highly encouraged through clinical trials. However, chemotherapy seems to only elicit a modest effect in avoiding recurrence in high risk and/or advanced disease. The administration of RT with concurrent adjuvant chemotherapy did not improve progression-free survival (PFS) and overall survival (OS) in the GOG-258 trial with 813 cases of stage III-IV EC, but significantly decreased vaginal and para-aortic recurrences compared 
to chemotherapy alone [13]. Similarly, results from the PORTEC-3 clinical trial suggested that adjuvant chemotherapy given during and after RT for high-risk endometrial cancer did not improve 5-year OS but did increase failure-free survival across several risk histologies [14]. Finally, in metastatic disease (stage IV), palliative surgery can be performed to alleviate specific symptoms. Additionally, radical RT (intrauterine BT \pm EBRT) or palliative RT should be taken in account to ameliorate patient's pain related to local recurrence or systemic disease.

\section{Signaling Pathways and Cellular Processes Modulating Radiotherapy Response in Endometrial Cancer and Preclinical Investigations}

\subsection{PI3K/PTEN/AKT/mTOR Signaling Pathway}

The PI3K/PTEN/AKT/mTOR signaling pathway is aberrantly activated in $80 \%$ of endometrioid ECs mostly due to PTEN loss [15]. Other molecular events are the amplification and mutations in phosphoinositide-3-kinase catalytic subunit alpha (PIK3CA) [16], mutations in PIK3 regulatory subunit 1 (R1) and PIK3KR2 [17]. Mutations in $A K T$, in particular $A K T 1$, are also present but infrequent, affecting $2 \%$ of type 1 ECs [18].

It has been shown that ionizing radiation activates PI3K/AKT/mTOR pathway in EC $[19,20]$, suggesting that its inhibition could elicit radiosensitization effects. Indeed, pharmaceutical inhibition of PI3K/mTOR by the dual PI3K/mTOR inhibitor NVP-BEZ235 sensitized five EC cell lines to RT [20]. Additionally, our group demonstrated that the inhibition of AKT by Sunitinib sensitized four EC cells lines to ionizing radiation [19], occurring only when total AKT inhibition was achieved [19]. In contrast, a study shows that most of the EC cell lines carrying oncogenic mutations in PIK3CA coexisting with PTEN mutations and with observed AKT activity were sensitive to RT [21].

Regarding PTEN, Mukherjee et al. demonstrated that PTEN improves DNA repair and prevents cell death in the EC Ishikawa cells transduced with PTEN or PTEN able to translocate to the nucleus when treated with the PARP inhibitor Olaparib [22]. For this reason, it is believed that PTEN loss could fail to provide effective DNA damage response after the double-strand breaks (DSBs) induced by RT. In fact, PTEN restoration renders Ishikawa cells more resistant to RT [19,22]. Additionally, RL95-2 cells (PTEN null) are more sensitive to RT than KLE cells (wild type) [19]. Overall, it seems that PTEN status predicts RT sensitivity in EC.

mTOR is a downstream effector of the PI3K/AKT signaling pathway that regulates the production of nutrients for the cell [23]. mTOR dysregulation is implicated in the tumorigenesis of many cancers, however, this is unclear for EC. The activity of mTOR has not been associated with a more aggressive phenotype in EC [24,25]. Regarding RT, little is known about the effects of RT in mTOR activation and the role of mTOR in RT sensitization in EC except for Kourea's study, which found a lack of correlation between the expression of phosphorylated mTOR in tissue microarrays of type 1 EC and RT use [25].

In order to determine the impact of mutations in the PTEN/PI3K/AKT pathway in EC, we performed an in silico analysis using public data sets from cBioPortal for cancer genomics including 1638 patients (Supplementary Material). Our analysis shows that mutations in AKT1 and in AKT2 are detrimental for OS, and that mutations in PTEN, PIK3CA, PIK3R1 and AKT3 were beneficial for OS and PFS (Figures S1 and S2). In the literature, the prognostic significance of mutations in PI3K-related genes for survival in EC was unclear. Different works have suggested that PIK3CA mutations have a favorable [26], unfavorable [27] or a neutral effect $[27,28]$ on patients' survival. In addition, one study showed that single mutations in PIK3CA and PIK3R1 were not a significant predictors of OS or PFS, after accounting for the tumor stage and grade [29]. PTEN mutations are associated with favorable pathological, clinical and molecular features rather than with increased metastatic potential in EC [15]. Specifically, loss of PTEN expression has been identified as an independent prognostic marker for favorable survival in EC [30]. Finally, AKT1 mutations have been restrictedly found in high grade, advanced stage EC [31], suggesting a detrimental effect in EC prognosis. 


\subsection{MAPK Signaling Pathway}

The mitogen-activated protein kinase (MAPK) superfamily has been linked to the growth factor-mediated regulation of diverse cellular events such as proliferation, senescence, differentiation and apoptosis. Oncogenic alterations in Ras/MAPK pathway occur in the form of activating KRAS mutations that have been detected in 6-16\% of cases of endometrial hyperplasia and $10-31 \%$ of cases of EC, being significantly higher in the MSI-positive ones [32]. Mutant KRAS promotes upregulation of MAPK and PI3K/AKT kinases, which further results in excessive cell proliferation and subsequently carcinogenesis. Several inhibitors of all these molecules, such as PD325901 or AZD6244, have been studied in EC and have been the subject of several anticancer targeted therapies [33,34].

Exposure of cells to ionizing radiation and a variety of other toxic stresses induces simultaneous compensatory activation of multiple MAPK pathway members controlling cell survival and repopulation effects following irradiation. Some of the signaling pathways activated are those normally activated by mitogens, such as the 'classical' MAPK (also known as the ERK) pathway, but also those downstream of death receptors, procaspases, and DNA-damage signals, including the JNK and P38 MAPK pathways [35]. Thus, the ability of radiation to activate MAPK signaling pathways may depend on the expression of multiple growth factor receptors, autocrine factors and RAS mutations, which basal expression can provide radiosensitivity or radioprotection. Specifically, in EC, two studies have related the MAPK pathway with ionizing radiation, both with the MEK inhibitor UO126. The first one was performed to predict radioresistance in EC cell lines, and the conclusion was that UO126 did not enhanced the effects of ionizing radiation, contrary to the PI3K/mTOR inhibitor NVP-BEZ235 [20]. The second work conducted for Marampon et al. was focused on the potential role of MEK/ERK inhibition on suppressing arising radioresistance mechanisms after irradiation [36]. There, treatment with U0126 increased radiosensitivity in a panel of gynecological cancer cell lines, with effects already evident at lowest radiation doses, suggesting that ERK inhibition enhances the response to DNA damage by radiation.

MYC is a transcription factor that can get activated by the MAPK pathway. MYC overexpression is highly prevalent in human malignancies [37,38]. In type 1 EC, MYC amplification has been associated with advanced and poorly differentiated disease [39]. Manning et al. have shown decreased MYC levels in the total blood in patients undergoing RT over the course of the fractionated schedule [40], the significance of which was not ascertained.

\subsection{NF- $\kappa B$ Signaling Pathway}

NF- $\kappa B$ is a family of dimeric transcription factors encoded by five genes: NF- $\kappa B 1, N F-\kappa B 2$, RelA (or p65), $c-R e l$ and RelB. NF- $k B 1$ and NF- $k B 2$ produce the precursor proteins p105 and p100, respectively that when proteolyzed by the proteasome form the mature proteins p50 and p52, respectively. Usually, the different dimers combinations are kept inactive in the cytoplasm facilitated by the inhibitory proteins IkBs. With the proper stimulus, IkBs get phosphorylated and consequently undergo proteasomal degradation liberating the NFKB dimers, which are then able to translocate to the nucleus to activate NFKB-dependent transcription [41].

The NF- $\mathrm{KB}$ signaling pathway is constitutively activated in many human malignancies [42] including EC [43]. It is widely known that chemotherapy and radiation increase NF- $\mathrm{kB}$ signaling and that NF- $\mathrm{KB}$ plays a role in chemo- and radioresistance in human cancers favoring tumor unresponsiveness, progression and metastasis [44]. This is in agreement with the work performed by Santacana and coauthors, where they found significantly higher nuclear translocation and thus activation of p50, c-Rel and RelB in post-radiation vaginal recurrences (PVRs) compared to primary ECs by immunohistochemistry (IHC) [45]. However, short time frames of $24 \mathrm{~h}$ of ionizing radiation $(1,1.5$ and 3 Gy) failed to significantly increase NF- $\mathrm{KB}$ transcriptional activity in Ishikawa cells $[19,45]$. In contrast, the blood of patients with EC subjected to RT present significant upregulation of BCL2L1 mRNA levels $24 \mathrm{~h}$ after the 25th fraction of RT ( 5 weeks from the first fraction) compared to $24 \mathrm{~h}$ after the first or the second fraction [40]. BCL2L1 encodes for Bcl- $\mathrm{X}_{\mathrm{L}}$ and $\mathrm{Bcl}-\mathrm{X}_{\mathrm{S}}$, which are NF-KB 
targets that act as an antiapoptotic and apoptotic proteins, respectively [46]. This suggests that long RT exposure activates the NF- $\mathrm{kB}$ pathway.

Another factor that has been well established since the early 50s to trigger RT resistance is hypoxia, due to the inability to generate DNA peroxides, which are the result of the interaction of reactive oxygen species (ROS) generated during water radiolysis with oxygen and the DNA [47]. Tumor hypoxia occurs when there is insufficient oxygen supply to the growing tumor despite the erratic and abnormal neo-vascularization developed to meet the demands. Many strategies have been investigated preclinically to target hypoxia and reverse radioresistance by means of increasing the delivery of oxygen, radiosensitizing hypoxic cancer cells or selectively killing them. However, only one made it to the clinic, nimorazole, an oxygen mimetic, for the treatment of head and neck cancers [48]. Hypoxia is controlled by hypoxia-inducible factor $1 \alpha$ (HIF- $1 \alpha)$. In EC, tumor vascularization and HIF-1 $\alpha$ expression have been associated to higher mortality in patients [49,50]. Preclinical studies in EC pointed out that the inhibition of PI3K/mTOR and subsequent HIF- $1 \alpha$ and VEGF-A downregulation increased the sensitivity to radiation in EC cell lines [20]. HIF-1 is activated by IKK $\beta$ [51]. Our group has previously discovered that hypoxia induces the translocation of p 65 and p52 to the nucleus thereby activating both canonical and alternative NF- $\mathrm{KB}$ pathways in EC [52]. The processing and consequently activation of p52 occurs in the absence of HIF- $1 \alpha$, unlike p65 activation [52]. HIF- $1 \alpha$ is highly expressed in recurrent ECs [53] including PVRs [45], where predominantly has a nuclear staining, compared to primary endometrial tumors. However, HIF- $1 \alpha$ does not translocate into the nucleus after $60 \mathrm{~min}$ of 1 and 3 Gy of radiation in Ishikawa cells [45]. All these studies suggest that the NF- $\mathrm{kB}$ pathway and hypoxia participate in the long-term process of adaptation of tumors to RT and that hypoxia precedes such adaptation. Upon radiation treatment, hypoxia activates NF- $\mathrm{kB}$, which leads to radioresistance prompting EC to reoccur.

\subsection{Growth Factor Receptors and Growth Hormone}

Growth factor receptors (GFR) are usually transmembrane proteins. They consist of an extracellular part responsible for a growth factor (GF) binding, a transmembrane part and an intracellular part that holds catalytic activity. The majority of GFR are receptor tyrosine kinases (RTKs). Others, like the TGF- $\beta$ receptor are serine-threonine kinases. The binding of the GF to the receptor leads to its activation and represents the first step in the initiation of cell proliferation and differentiation cascades. Gain-of-function mutations, amplification and epigenetic changes in GFR have been implicated in cancer initiation and progression. It has been shown that GFR alterations confer resistance to RT in several cancers, such as epidermal GFR (EGFR) in glioblastoma [54] or fibroblast GFR (FGFR) in squamous cell carcinoma [55]. In EC, the role of GFR in inducing radioresistance is not well understood and it has been limitedly addressed.

We have recently demonstrated that ionizing radiation enhances the phosphorylation of the RTK c-Kit in Ishikawa cells and that the multi-RTK inhibitor Sunitinib abrogated such phosphorylation and rendered cells more sensitive to RT, suggesting a primordial role of c-Kit in sensitizing c-Kit+ ECs to RT [19]. c-Kit also seems important for the progression of EC as $25 \%$ and $40 \%$ of recurrent endometrioid carcinomas and uterine papillary serous carcinomas, respectively, presented positive staining for c-Kit while this RTK was absent in primary tumors [56].

EGFR is overexpressed in $46 \%$ and $34 \%$ of type 1 and type 2 ECs, respectively [57]. Some works suggest that EGFR overexpression could confer RT resistance and its inhibition could promote radiosensitivity in EC. For example, Shi et al. observed that EC xenografts made of radiation resistant cells slowed down their growth when EGFR was knocked-down by shRNA [58]. Additionally, photodynamic therapy with the photosensitizer radachlorin, able to generate ROS upon laser irradiation, downregulated the protein levels of EGFR in the EC cell line HEC-1-A $48 \mathrm{~h}$ after irradiation, concurrently with caspase-9 activation [59].

Regarding VEGFR, a study has shown higher expression of phosphorylated VEGFR2 in $44.5 \%$ of endometrioid carcinomas by IHC, which was linked with higher VEGF levels in patients' total blood 
undergoing RT compared to benign disease and control patients [60]. Our group discovered expression of VEGFR2 in two out of the four EC cell lines analyzed (Ishikawa and KLE). Interestingly, these two cell lines were also resistant to ionizing radiation and Sunitinib induced RT sensitization [19]. In a similar manner to EGFR, photodynamic therapy reduced the expression of VEGFR2 at $8 \mathrm{~h}$ post-irradiation and effectively induced apoptosis in HEC-1-A cells [59]. The utility of VEGF inhibition as a radiosensitizer in EC was demonstrated in a clinical trial (NCT00545792) with 15 women with recurrent EC that were treated with the humanized monoclonal antibody bevacizumab with concurrent RT [61]. Notably, none of them experienced local relapse within the radiated field during a median of four-year follow-up [61].

Growth hormone (GH) or somatotropin is a 191-amino acids peptide hormone secreted by the anterior pituitary gland and extra-pituitary tissue that stimulates growth and metabolism. High human (h) GH expression has been associated with lymph node metastasis, higher tumor stage, grade, myometrial invasion as well as worse prognosis in EC [62]. RL95-2 cells forcibly expressing hGH displayed a more aggressive phenotype and tumorigenic capacity in murine xenografts [63] as well as sensitivity to mitomycin C-induced DNA damage in vitro [64]. Bougen et al. demonstrated that treatment with the hGH receptor antagonist B2036 and ionizing radiation (4 Gy) synergistically reduced cell clonogenic survival and increased radiation-induced-DNA damage in RL95-2 cells [65]. One step further was done in 2016 by Evans et al. with the utilization of a pegylated form of B2036 (pegvisomant, Pfizer) in a RL95-2 xenograft model. The group demonstrated that the subcutaneous administration of pegvisomant at $100 \mathrm{mg} / \mathrm{Kg}$ significantly delayed tumor regrowth following exposure to fractionated ionizing radiation in mice through an unclear mechanism [66]. A representation of the above-mentioned signaling pathways playing a role in RT sensitivity can be found in Figure 1.

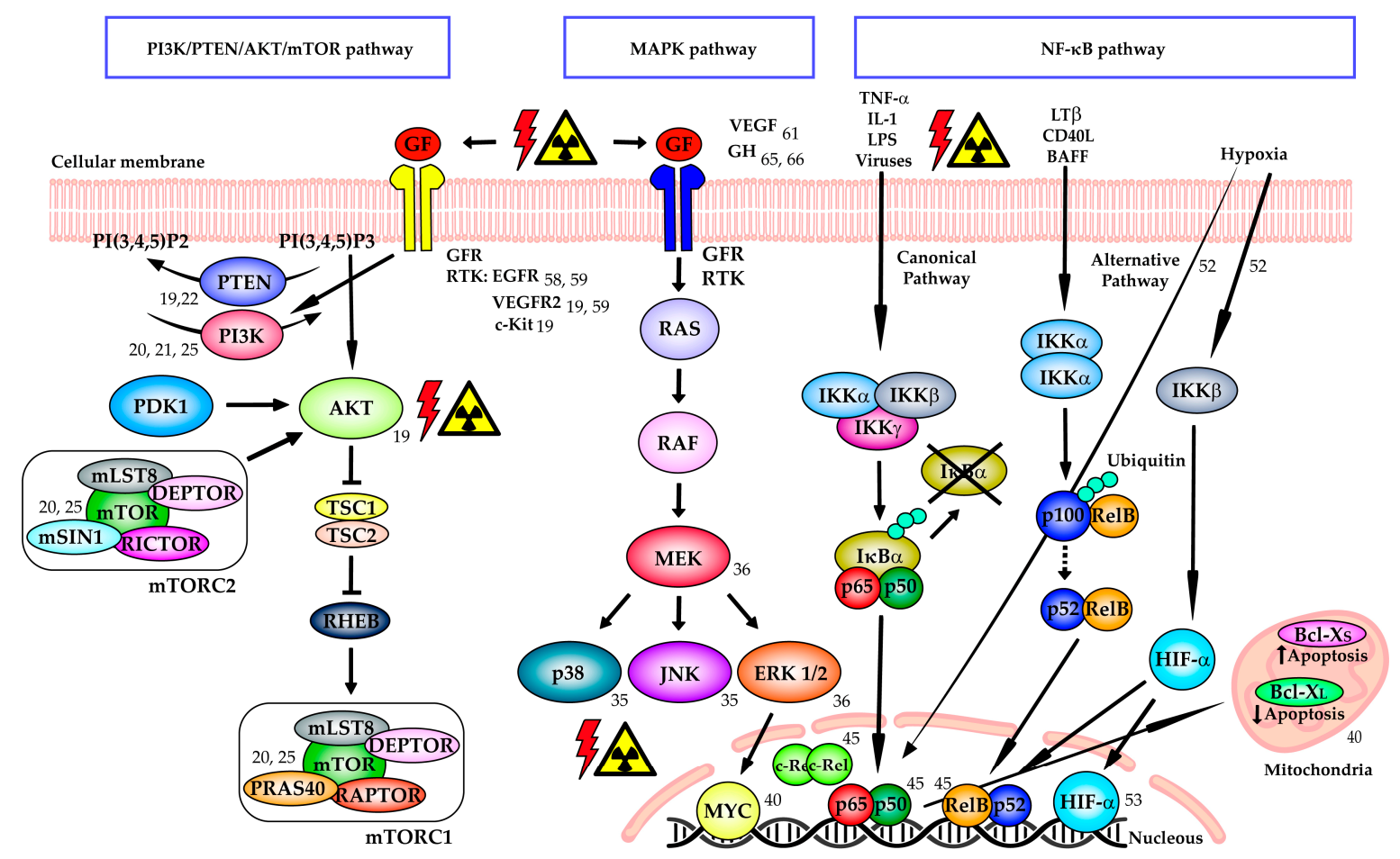

Figure 1. Participation of PI3K/PTEN/AKT/mTOR, MAPK and NF- $\mathrm{B}$ s signaling pathways in sensitivity to radiotherapy in endometrial cancer. Schematic representation of the signaling pathways and some of their members playing a role in sensitivity to ionizing radiation in endometrial cancer. References of the studies performed in endometrial tissues, cells or animal models are indicated for each target. Abbreviations: GF: growth factor, GFR: growth factor receptor, RTK: receptor tyrosine kinase, TNF- $\alpha$ : tumor necrosis factor alpha, IL-1: interleukin-1, LPS: lipopolysaccharide, LT $\beta$ : lymphotoxin-beta, CD40L: cluster of differentiation 40 ligand, BAFF: B-cell activating factor. 


\subsection{DNA Repair Mechanisms}

RT induces cell death mostly due to DNA damage, especially DSBs. Consequently, tumor cells with highly efficient DNA damage response (DDR) machineries are radioresistant, whereas cancer cells with deficient DNA repair pathways are radiosensitive [67]. Therefore, therapies that inhibit the DNA repair process have the potential to enhance RT efficacy [68] (Figure 2).

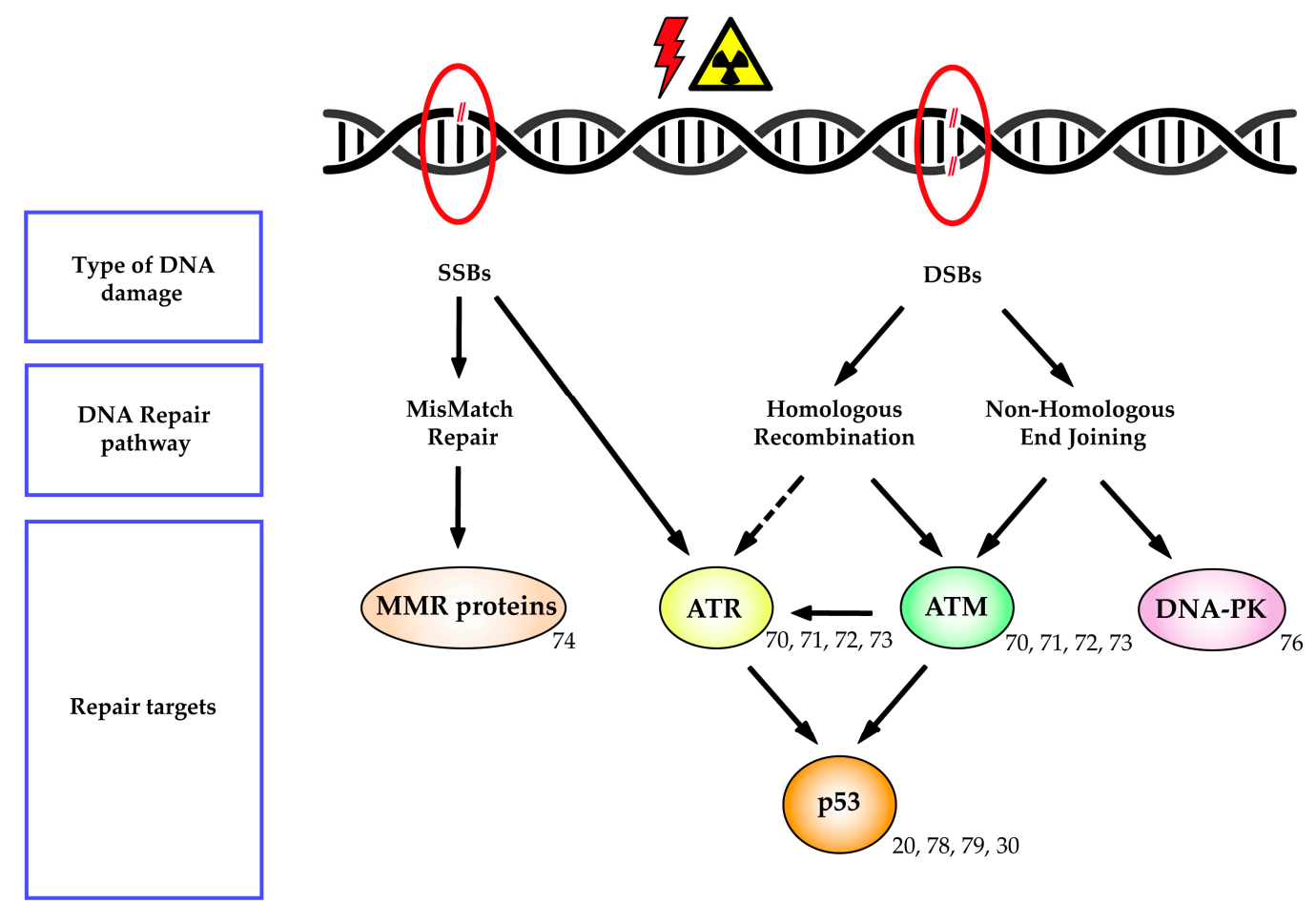

Figure 2. Activation of DNA repair mechanisms and their involvement in radiotherapy sensitivity in endometrial cancer. Scheme of the DNA repair pathways and targets activated by ionized radiation in EC. References of the studies performed in endometrial tissues or cells are indicated for each target. Abbreviations: single-strand breaks (SSBs), double-strand breaks (DSBs), mismatch repair (MMR), ataxia telangiectasia mutated (ATM), ataxia telangiectasia and Rad3-related (ATR), DNA-dependent protein kinase (DNA-PK).

Key regulators of the DDR are ataxia-telangiectasia-mutated (ATM) and ataxia telangiectasia and Rad3-related (ATR) proteins. ATM responds primarily to DSBs whereas ATR protects the integrity of replicating chromosomes. They belong to the class-IV phosphoinositide 3-kinase-related kinase (PIKK) family and their activation induces phosphorylation of its downstream targets, such as Chk1 (checkpoint kinase 1) or Chk2 (checkpoint kinase 2), and regulates cell cycle and DNA repair [69]. Various studies in EC cell lines evidenced that pharmacologic inhibition of ATR and ATM enhances the cytotoxic effect of radiation [70,71]. Moreover, homologous recombination (HR), mainly promoted by ATM and ATR, deficiency is common in ECs as proved from the results obtained using a functional RAD51-IRIF assay, where several EC samples were irradiated to induce DNA DSBs [72]. HR is also associated with cervical and endometrial tumor response to RT [73].

The MMR system is responsible for repairing base mismatches and includes the MMR proteins hMLH1, hMSH2, hPMS2, hMSH3 and hMSH6. Aberrations in MMR genes are involved in carcinogenesis of EC type I and mutations in $h M L H 1$ have been detected in $20-40 \%$ of EC cases [32]. Regarding RT, a recent paper concluded that adjuvant RT improved survival in EC MMR-deficient patients and that MMR status could be used as a predictive biomarker to select patients that benefit most from adjuvant RT [74]. 
DSBs, apart from HR, could be repaired by non-homologous end joining (NHEJ) activated by the DNA-dependent protein kinase (DNA-PK) complex, among other factors. DNA-PK is a trimetric enzyme consisting of a 460-kDa catalytic subunit (DNA-PKcs) and a heterodimeric regulatory complex called $\mathrm{Ku}$, which is composed of $70 \mathrm{kDa}$ protein $(\mathrm{Ku} 70)$ and $86 \mathrm{kDa}$ protein $(\mathrm{Ku} 80)$ subunits [75]. Low Ku70 expression is associated with better PFS in EC, probably due to a major sensitivity of tumors to RT [76].

p53 is a tumor suppressor known to be post-translationally modified, stabilized and activated in response to cellular stress such as DNA damage, oncogene expression or ribosome dysfunctions and activates the transcription of numerous genes implicated in cell cycle arrest, DNA repair, apoptosis and senescence [77]. The TP53 gene is mutated approximately in half of human cancers and in $90 \%$ of type II ECs, but only in 10-20\% of Grade 3 type I ECs [32]. The effects of cellular exposure to irradiation on p53 activation are well-known but studies deciphering the role of p53 status in RT sensitivity in EC have given contrasting results. An old study did not correlate TP53 mutations with radiosensitivity in gynecological cancer cell lines [78]. Similarly, women with endometrioid carcinomas with TP53 alterations did not show differences in OS after receiving adjuvant RT compared to women with wild-type TP53 [79]. In contrast, other experiments in EC cell lines demonstrated that wild-type TP53 cell lines were more sensitive to radiation than the TP53-mutated ones [20]. In the same line, another work demonstrated significant p53 overexpression in type $2 \mathrm{EC}$, which was associated with advanced stage and poorer OS after adjuvant RT [30]. Conversely, one study confirmed that patients with endometrioid carcinomas harboring TP53 alterations benefited greater from adjuvant RT than the wild-type ones [79].

\subsection{Immune System}

The first studies establishing associations between the immune system and RT in EC indicated that RT decreased peripheral blood T-cell numbers [80]. Nevertheless, now is recognized that a component of tumor damage after radiation may be due to immunogenic cell death. Radiation induces immunostimulation through the release of tumor antigens, cytokines, chemokines and increases expression of death receptors and other molecules that contribute to recognition of tumor cells by the immune system [81]; and most importantly, alters the microenvironment within the irradiated field, increasing the density of tumor infiltrating lymphocytes (TILs).

Therapies based on immune checkpoint inhibitors, mainly the cytotoxic T-lymphocyte-associated protein 4 (CTLA-4) and programmed-death receptor 1 (PD-1), demonstrated significantly poorer response rates in gynecologic tumors $[82,83]$ with the remarkable exception of PD-1 inhibitors for the treatment of microsatellite instability-high (MSI-High) or mismatch repair-deficient (dMMR) metastatic ECs [84]. These two subgroups have been shown to possess high neoantigen loads and increased number of TILs together with PD-1 and programmed death-ligand 1 (PD-L1) overexpression [85]. For this reason, the combination of immunotherapy with radiation in EC has recently generated great interest. The immunologic properties of radiation may complement the immune stimulatory effects of both CTLA-4 and PD-1 pathway inhibition, as preclinical studies have demonstrated synergies with both classes of agents and radiation in terms of improved local and distant control, including abscopal regression of established tumors outside of the radiation treatment field [86]. Based on these findings, a wide range of RT doses and fractionation schedules have been proposed for optimal combination with immunotherapy in studies deploying mice models. There, it is shown that the efficacy of low doses of fractionated RT can be enhanced when delivered in combination with antibodies against PD-1 and PD-L1 [87]. Currently, there are several ongoing clinical trials in patients with advanced uterine cancers testing monoclonal antibodies against key immune checkpoint inhibitors, such as durvalumab (PD-1), pembrolizumab (PD-1), tremelimumab (CTLA-4) or TSR-042 (PD-1), administrated simultaneously or sequentially to RT [88]. 


\subsection{Others}

Besides the signaling pathways and proteins exposed above, there are other unrelated markers that have a role in RT sensitivity that deserve special attention. One of these is PTTG, the pituitary tumor transforming gene. PTTG is involved in many biological and tumoral processes including chromatid separation, DNA repair, organ development, angiogenesis and metastasis. PTTG has been found overexpressed in brain tumors and pituitary adenomas $[89,90]$. Silencing PTTG expression by siRNA inhibited the growth of the EC cell line HEC-1A and potentiated the effects of RT in cell growth inhibition and apoptosis induction [91]. Another important biomarker is Hsp70, product of the HSP70 gene, a heat shock protein involved in protein folding and expressed under cellular stress. Hsp70 has often been found to be overexpressed in cancer cells because they rely on its protective survival properties [92]. Silencing HSP70 expression enhances the therapeutic effect of RT in EC cells [93]. The G2/M checkpoint is another interesting target in cancer as many tumors are defective in G1/S checkpoint and rely on G2/M for cell division and survival. It is fairly screened for drugs, particularly those targeting Plk and Chk proteins. Plk1 is found overexpressed in EC tissue [94] and abrogation of Chk1, Chk2 and Plk1 expression in EC cells potentiates the antitumor efficacy and apoptosis induced by cisplatin or radiation [94,95]. Another interesting protein related to RT response is osteopontin-1 (OPN). OPN, encoded by the SPP1 gene, is a secreted phosphorylated glycoprotein initially found in the extracellular matrix of the bone and widely expressed across tissues [96]. OPN has also been identified as a hypoxia-responsive protein, being associated with radiation resistance mechanisms in lung and breast cancer cells $[97,98]$. In EC, inhibition of OPN renders EC cells more susceptible to RT [99]. In the clinical setting, elevated OPN levels in plasma predict poor disease outcomes in patients with head and neck cancer [100] and breast cancer [101].

EC is a hormone dependent disease where the expression of estrogen receptor (ER) and progesterone receptor $(\mathrm{PgR})$ has been associated with histological tumor differentiation, response to therapy and metastatic potential. In particular, loss of ER, PgR-A and PgR-B are key events of endometrial carcinogenesis and the predominance of some isoforms respect others can explain some clinical features [102]. For example, patients with a ratio PgR-A/Pgr-B lower than 1 have shorter OS and PFS [103]. In general, patients with ER+ and/or PgR+ tumors present a good response to hormone therapy and could even confer radiosensitivity. Primary explants of highly differentiated ECs showed enhanced radiosensitivity when treated with medroxyprogesterone, a progestogen [104].

The ARG1 gene encodes for arginase 1 enzyme, which controls the last step of the urea cycle, where arginine is hydrolyzed to form ornithine and urea. Recent studies confirm that ARG1 is expressed in activated M2 macrophages and participates in anti-inflammation, tumor immunity, tumor proliferation, metastasis and immunosuppression-related diseases [105]. One study found upregulation of $A R G 1$ expression in EC patients' total blood, which was sustained at least 5 weeks after the first irradiation delivery, suggesting that $A R G 1$ expression level could be a predictive biomarker of late RT irradiation exposure [40].

It has been described that efflux pumps play a role in chemotherapy and RT resistance. One example is P-glycoprotein, a membrane protein ATP-driven drug efflux pump, which is associated with multidrug resistance and found overexpressed in many tumors [106] including EC [107]. P-glycoprotein confers resistance to RT and suppresses radiation-induced apoptosis in ovarian and lymphoma cancer cells [108]. Cancer stem cells (CSCs) also overexpress drug efflux pumps and have an enhanced DNA damage repair machinery and activation of mitogenic and antiapoptotic pathways, altogether leading to chemotherapy and RT resistance [109]. It has been postulated that the remaining CSC present after RT administration could be responsible of cancer relapse [110]. In EC, CSCs play a role in EC initiation, metastasis and overall chemo- and radioresistance through the activation of the epithelial-to-mesenchymal transition (EMT) program, Hedgehog, PI3K/AKT/mTOR and NOTCH signaling pathways [111]. However, possible radiosensitization effects resulting from the suppression of CSC have not yet directly been evaluated in EC. In this line, we demonstrated that inhibition of c-Kit signaling, a CSC marker [111], by Sunitinib sensitizes Ishikawa cells to ionizing radiation [19]. 
Additionally, PTEN/PI3K/AKT/mTOR pathway favors stemness through the upregulation of EMT inducers [112] and its inhibition induces radiosensitization [20].

\section{Functional Assays that Assess Radiosensitivity}

The most commonly used in vitro functional assays for assessing radiosensitivity are clonogenic assays, determination of micronuclei frequencies and detection of $\gamma$-H2AX. Clonogenic assays determine the ability of cancer cells to form colonies ( $>50$ cells) over a certain period of time, usually 1-3 weeks [113]. After a radiotherapeutic insult, such an ability is compromised [19]. The clonogenic assay provides the fraction of reproductive cells remaining after irradiation. The sensitivity of the assay is high as it detects minor changes in survival; the effect is expressed in the logarithmic scale. The specificity is low, as other treatments, such as chemotherapeutic drugs, can reduce clonogenicity. One limitation of the clonogenic assays is the long time required for the obtainment of the result. Additionally, the assay is unable to differentiate between dead and non-proliferating colonies. The formation of radiation-induced micronuclei refers to the formation of chromatin particles originated from whole chromosomes or fragments of them during mitosis as a result of radiation [114]. Similar to clonogenic assays, tests aiming to determine micronuclei have high sensitivity and low specificity. Micronuclei can easily be detected by in situ hybridization (FISH) of centromeres or by regular nucleic acid stains [115]. However, one limitation is its low specificity since the formation of micronuclei occurs both under normal physiologic conditions and drug treatments. $\gamma-\mathrm{H} 2 \mathrm{AX}$ is a known marker of DNA double-strand breaks, which are one of the consequences of ionizing radiation. This phosphorylation in histone $\mathrm{H} 2 \mathrm{AX}$ can be detected and quantified by several techniques including Western blot or immunofluorescence [19]. $\gamma-\mathrm{H} 2 \mathrm{AX}$ is a measure of radiosensitivity and disappears once the cell repairs the DNA damage. The $\gamma$-H2AX analysis possesses high sensitivity as the detection involves the use of antibodies conjugated usually to fluorophores [19]. Additionally, it has higher specificity compared to clonogenic assays and micronuclei tests due to the detection of a very specific type of DNA damage. However, the transiency of the phosphorylation in H2AX is a limitation of the technique. In addition, the assay is unable to distinguish between faithful DNA repair and misrepair and between simple and complex DNA damage [116].

\section{Current Clinical Trials Employing Agents with Radiosensitization Properties in Endometrial Cancer}

The choice of adjuvant treatment for each EC's risk group is supported by the results of clinical trials. However, it is still today a matter of intense debate [117]. Multiple untargeted drugs have been studied in combination with RT for EC treatment. These include taxanes (docetaxel and paclitaxel), platinum compounds (cisplatin and carboplatin), anthracyclines (doxorubicin), nucleotide analogs and precursors (gemcitabine, capecitabine and 5-fluorouracil) and vinca alkaloids and derivatives (vinorelbine) [118-120]. In contrast, a lack of targeted adjuvant treatments is emphasized.

In this section, we will discuss the targeted therapies utilized for inhibiting or activating cellular pathways known to play a role in radiation resistance or sensitivity, in combination with RT in EC. There are currently ten clinical trials, which have evaluated or are evaluating the efficacy of such targeted therapies (Table 1). These can be classified in GF/GH inhibitors (bevacizumab and octreotide), PARP inhibitors (talazoparib) and immune system modulators (filgrastim, pegfilgrastim, pembrolizumab, durvalumab, tremelimumab and TSR-042). We will also discuss in this section the most recent clinical trials, either recently completed or currently active, employing chemotherapy in combination with radiotherapy in EC (Table 2). 
Table 1. Clinical Trials with Targeted Therapies with Radiosensitization Properties.

\begin{tabular}{|c|c|c|c|c|c|c|c|c|}
\hline $\begin{array}{l}\text { Trial Name, } \\
\text { Identifier } \\
\text { And [Status] }\end{array}$ & Phase & $\mathbf{N}$ & Official Name & $\begin{array}{l}\text { Type of EC } \\
\text { Included }\end{array}$ & $\begin{array}{l}\text { Drugs and Treatment } \\
\text { Scheme }\end{array}$ & $\begin{array}{l}\text { Radiation Regimen and } \\
\text { Schedule }\end{array}$ & $\begin{array}{l}\text { Primary } \\
\text { Outcomes }\end{array}$ & Secondary Outcomes \\
\hline \multicolumn{9}{|c|}{ Growth factors-Growth factor inhibitors } \\
\hline $\begin{array}{l}\text { NCT01005329 } \\
\text { [Completed] }\end{array}$ & II & 34 & $\begin{array}{l}\text { A Phase II Study of } \\
\text { Postoperative Intensity } \\
\text { Modulated Radiation } \\
\text { Therapy (IMRT) With } \\
\text { Concurrent Cisplatin and } \\
\text { Bevacizumab Followed } \\
\text { by Carboplatin and } \\
\text { Paclitaxel for Patients } \\
\text { With Endometrial Cancer }\end{array}$ & $\begin{array}{l}\text { Resected high-risk } \\
\text { stage I-IV EC }\end{array}$ & $\begin{array}{c}\text { Bevacizumab } \\
\text { (anti-VEGF), and } \\
\text { cisplatin, followed by } \\
\text { carboplatin and paclitaxel }\end{array}$ & $\begin{array}{l}\text { Pelvic IMRT once daily, } \\
5 \text { days a week, for } 5 \text { weeks } \\
\text { (45 Gy in } 25 \text { fractions) with } \\
\text { optional nodal boost RT } \\
\text { and/or vaginal BT boost. } \\
\text { Concurrently with } \\
\text { bevacizumab+cisplatin. }\end{array}$ & $\begin{array}{l}\text { Adverse events } \\
\text { by grade within } \\
90 \text { days after the } \\
\text { treatment starts }\end{array}$ & $\begin{array}{l}\text { Adverse events by grade } \\
\text { within } 90 \text { days within } 1 \text { year } \\
\text { treatment start and from start } \\
\text { of treatment to end of } \\
\text { follow-up, up to } 43.4 \text { months; } \\
\text { OS, DFS, pelvic failure rate } \\
\text { and distant failure }\end{array}$ \\
\hline $\begin{array}{l}\text { NCT00545792 } \\
\text { [Completed] }\end{array}$ & II & 21 & $\begin{array}{l}\text { A Pilot Study Evaluating } \\
\text { The Safety Of Avastin } \\
\text { And Pelvic Radiation In } \\
\text { Women With } \\
\text { Pelvic-Confined } \\
\text { Recurrence of } \\
\text { Gynecological Cancers }\end{array}$ & $\begin{array}{c}\text { Recurrent } \\
\text { pelvic-confined EC }\end{array}$ & Bevacizumab & $\begin{array}{l}\text { Daily Pelvic RT. } \\
\text { Concurrently with } \\
\text { bevacizumab. }\end{array}$ & $\begin{array}{l}\text { PFS } \\
\text { OS }\end{array}$ & $\begin{array}{l}\text { Thrombosis and one embolic } \\
\text { event in the setting of } \\
\text { metastatic disease }\end{array}$ \\
\hline $\begin{array}{l}\text { NCT00033605 } \\
\text { [Completed] }\end{array}$ & III & 130 & $\begin{array}{l}\text { Phase III Double-Blind } \\
\text { Study Of Depot } \\
\text { Octreotide Versus } \\
\text { Placebo In The } \\
\text { Prevention Of Acute } \\
\text { Diarrhea In Patients } \\
\text { Receiving Pelvic } \\
\text { Radiation Therapy }\end{array}$ & $\mathrm{EC}$ & $\begin{array}{l}\text { Octreotide (GH inhibitor) } \\
\text { Arm I: Short-acting } \\
\text { octreotide SC on day } 1 \\
\text { and long-acting } \\
\text { octreotide IM on days } 2 \\
\text { and } 29 . \\
\text { Arm II: Patients receive } \\
\text { placebo SC on day } 1 \text { and } \\
\text { IM on days } 2 \text { and } 29\end{array}$ & $\begin{array}{l}\text { Prior planned cumulative } \\
\text { dose of RT, including boost } \\
\text { fields ( } 4500-5350 \text { cGy vs. } \\
5351-6000 \text { cGy vs. more } \\
\text { than } 6000 \text { cGy) and } \\
\text { planned intracavitary BT. } \\
\text { RT starts maximum } 4 \text { days } \\
\text { before octreotide. }\end{array}$ & $\begin{array}{l}\text { Reduction of } \\
\text { diarrhea } \\
\text { measured } \\
\text { weekly during } \\
\text { pelvic RT up to } \\
2 \text { years }\end{array}$ & $\begin{array}{l}\text { Reduction of } \\
\text { patient-reported bowel } \\
\text { dysfunction, toxicity and } \\
\text { importance that patients } \\
\text { attach to various measures of } \\
\text { bowel dysfunction as } \\
\text { assessed by questionnaire }\end{array}$ \\
\hline
\end{tabular}


Table 1. Cont

\begin{tabular}{|c|c|c|c|c|c|c|c|c|}
\hline \multicolumn{9}{|c|}{ DNA repair pathway-PARP inhibitors } \\
\hline $\begin{array}{l}\text { NCT03968406 } \\
\text { [Recruiting] }\end{array}$ & I & 24 & $\begin{array}{l}\text { Phase I Study of } \\
\text { Talazoparib in } \\
\text { Combination With } \\
\text { Radiation Therapy for } \\
\text { Locally Recurrent } \\
\text { Gynecologic Cancers }\end{array}$ & $\begin{array}{l}\text { Stage IV or } \\
\text { recurrent EC }\end{array}$ & $\begin{array}{c}\text { Talazoparib (PARP } \\
\text { inhibitor) }\end{array}$ & $\begin{array}{l}\text { Fractionated RT } 5 \text { days per } \\
\text { week for up to } 7 \text { weeks. } \\
\text { Concurrently with } \\
\text { talazoparib. }\end{array}$ & MTD & $\begin{array}{l}\text { Adverse events, RR, PFS, OS. } \\
\text { Others: PAR inhibition levels, } \\
\text { Y-H2AX and RAD51 foci } \\
\text { formation levels, OQL }\end{array}$ \\
\hline \multicolumn{9}{|c|}{ Immunotherapy-Immune system activators and immune checkpoints inhibitors } \\
\hline $\begin{array}{l}\text { GOG-0184 } \\
\text { NCT00006011 } \\
\text { [Completed] }\end{array}$ & III & 659 & $\begin{array}{c}\text { A Randomized Phase III } \\
\text { Study of Tumor Volume } \\
\text { Directed Pelvic Plus or } \\
\text { Minus Para-Aortic } \\
\text { Irradiation Followed by } \\
\text { Cisplatin and } \\
\text { Doxorubicin or Cisplatin, } \\
\text { Doxorubicin and } \\
\text { Paclitaxel for Advanced } \\
\text { Endometrial Carcinoma }\end{array}$ & Stage III or IV EC & $\begin{array}{l}\text { Filgrastim (G-CSF analog) } \\
\text { or pegfilgrastim } \\
\text { (pG-CSF analog) } \\
\text { Arm I: doxorubicin and } \\
\text { cisplatin, followed by } \\
\text { G-GSF or pGCSF } \\
\text { Arm II: doxorubicin and } \\
\text { cisplatin, followed by } \\
\text { paclitaxel and followed } \\
\text { by G-GSF or pGCSF }\end{array}$ & $\begin{array}{l}\text { Pelvic or extended field RT. } \\
\text { Within } 8 \text { weeks after } \\
\text { surgery, patients receive } \\
\text { tumor VDPR with or } \\
\text { without PNR once daily for } \\
5 \text { consecutive days for up } \\
\text { to } 16 \text { weeks after surgery. } \\
\text { Within } 8 \text { weeks of } \\
\text { completing RT, patients } \\
\text { receive Arm I or Arm II. }\end{array}$ & RFS & Not provided \\
\hline $\begin{array}{l}\text { PRIMMO } \\
\text { NCT03192059 } \\
\text { [Recruiting] }\end{array}$ & II & 43 & $\begin{array}{l}\text { A Phase II Investigation } \\
\text { of Pembrolizumab } \\
\text { (Keytruda) in } \\
\text { Combination With } \\
\text { Radiation and an } \\
\text { Immune Modulatory } \\
\text { Cocktail in Patients With } \\
\text { Cervical and Uterine } \\
\text { Cancer (PRIMMO Trial) }\end{array}$ & $\begin{array}{l}\text { Advanced and } \\
\text { refractory EC }\end{array}$ & $\begin{array}{l}\text { Pembrolizumab } \\
\text { (anti-PD-1) } \\
\text { vitamin D, aspirin, } \\
\text { cyclophosphamide, } \\
\text { lansoprazole and } \\
\text { curcumin }\end{array}$ & $\begin{array}{l}\text { EBR } 24 \text { Gy in } 3 \text { fractions, a } \\
\text { fraction every } 8 \mathrm{~h} \\
\text { Concurrently with } \\
\text { drug scheme. }\end{array}$ & ORR at week 26 & $\begin{array}{c}\text { Incidence of adverse events, } \\
\text { ORR, best OR, PFS, OS and } \\
\text { OQL assessment }\end{array}$ \\
\hline
\end{tabular}


Table 1. Cont.

\begin{tabular}{|c|c|c|c|c|c|c|c|c|}
\hline $\begin{array}{l}\text { FIERCE } \\
\text { NCT03932409 } \\
\text { [Recruiting] }\end{array}$ & I & 20 & $\begin{array}{c}\text { A Phase Ib Trial of Vaginal } \\
\text { Cuff Brachytherapy + } \\
\text { Pembrolizumab (MK3475) } \\
\text { Followed by } 3 \text { Cycles of } \\
\text { Dose Dense Paclitaxel/q } 21 \\
\text { Day Carboplatin + } \\
\text { Pembrolizumab (MK3475) } \\
\text { in High Intermediate Risk } \\
\text { Endometrial Cancer }\end{array}$ & $\begin{array}{c}\text { High and } \\
\text { intermediate-risk EC }\end{array}$ & $\begin{array}{l}\text { Pembrolizumab (anti-PD-1) } \\
\text { and chemoradiation } \\
\text { consisting of dose dense } \\
\text { paclitaxel and carboplatin } \\
\text { and, BT }\end{array}$ & $\begin{array}{l}\text { Vaginal cuff BT given one } \\
\text { week after pembrolizumab. }\end{array}$ & $\begin{array}{l}\text { Patients } \\
\text { completing } 3 \\
\text { cycles of } \\
\text { pembrolizumab }\end{array}$ & $\begin{array}{c}\text { PFS } \\
\text { OS } \\
\text { Adverse event frequency }\end{array}$ \\
\hline $\begin{array}{l}\text { NCT04214067 } \\
\text { [Recruiting] }\end{array}$ & III & 168 & $\begin{array}{l}\text { A Phase III Randomized } \\
\text { Trial of Radiation } \pm \\
\text { MK-3475 (Pembrolizumab) } \\
\text { for Newly Diagnosed Early } \\
\text { Stage High Intermediate } \\
\text { Risk Mismatch Repair } \\
\text { Deficient (dMMR) } \\
\text { Endometrioid } \\
\text { Endometrial Cancer }\end{array}$ & $\begin{array}{l}\text { High-intermediate risk } \\
\text { stage I-II dMMR EC }\end{array}$ & $\begin{array}{c}\text { Pembrolizumab (anti-PD-1) } \\
\text { Arm 1: EBRT + BT } \\
\text { Arm 2: ERBT + BT + } \\
\text { Pembrolizumab } \\
\text { administered } 7 \text { days prior to } \\
\text { the start of RT, every } 3 \text { weeks } \\
\text { for up to } 1 \text { year (17 cycles) }\end{array}$ & $\begin{array}{l}\text { ERBT daily for } 5-6 \text { weeks } \\
\text { and vaginal BT completed } \\
\text { within } 7 \text { days after } \\
\text { completion of EBRT. } \\
\text { Pembrolizumab given } 7 \\
\text { days prior to the start of RT. }\end{array}$ & 3-year RFS & $\begin{array}{c}\text { Incidence of adverse effects, } \\
\text { recurrence patterns, 5-year } \\
\text { RFS, OS, patients } \\
\text { reported outcomes }\end{array}$ \\
\hline $\begin{array}{l}\text { NCT03277482 } \\
\text { [Recruiting] }\end{array}$ & I & 23 & $\begin{array}{c}\text { A Phase } 1 \text { Study of } \\
\text { Durvalumab, } \\
\text { Tremelimumab and } \\
\text { Radiotherapy in Recurrent } \\
\text { Gynecologic Cancer }\end{array}$ & $\begin{array}{l}\text { Recurrent and } \\
\text { metastatic EC }\end{array}$ & $\begin{array}{c}\text { Durvalumab (anti-/PD-L1) + } \\
\text { Tremelimumab } \\
\text { (anti-CTLA-4) }\end{array}$ & $\begin{array}{l}\text { EBT hypofractionated short } \\
\text { course (either } 1 \text { or } 5 \text { days). } \\
\text { Concurrently with the } \\
\text { immunotherapies. }\end{array}$ & MTD & $\begin{array}{c}\text { ORR, LRR, LCR, ARR, RD, } \\
\text { PFS, OS }\end{array}$ \\
\hline $\begin{array}{l}\text { NCT03955978 } \\
\text { [Recruiting] }\end{array}$ & I & 12 & $\begin{array}{l}\text { A Phase I Study of PD-1 } \\
\text { Inhibition With TSR-042 in } \\
\text { Addition to Standard of } \\
\text { Care Definitive Radiation } \\
\text { for Inoperable } \\
\text { Endometrial Cancer }\end{array}$ & Inoperable EC & TSR-042 (anti-PD-1) & $\begin{array}{l}\text { BT } 36 \text { Gy in } 6 \text { fractions, } \\
\text { given weekly. } \\
\text { The first dose of TSR-042 is } \\
\text { administered } 21 \text { days prior } \\
\text { to the first BT fraction. }\end{array}$ & $\begin{array}{l}\text { Adverse event } \\
\text { at six weeks }\end{array}$ & PFS \\
\hline
\end{tabular}
Abbreviations: ARR: abscopal response rate; BT: brachytherapy; CTLA-4: cytotoxic T-lymphocyte-associated protein 4; DFS: disease free survival; dMMR: deficient mismatch repair; EBT:
external beam therapy; G-CSF: granulocyte-colony stimulating factor; IM: intramuscularly; Intensity-modulated radiation therapy: IMRT; IV: intravenously; LCR: local control rate; LRR: loco-regional recurrence; MTD: maximum tolerated dose; OQL: overall quality of life; ORR: overall response rate; OS: overall survival; PD-1: programmed cell death-1; PD-L1; programmed death-ligand 1; PFS: progression-free survival; PNR: para-aortic nodal radiotherapy; RD: response duration; RFS: recurrence-free survival; RR: response rate; RT: radiotherapy; VDPR: volume-directed pelvic radiotherapy; VEGF: vascular endothelial growth factor. 
Table 2. Recently Closed and Active Clinical Trials Employing Chemotherapy Combined with Radiotherapy.

\begin{tabular}{|c|c|c|c|c|c|c|c|c|}
\hline $\begin{array}{l}\text { Trial Name, } \\
\text { Identifier and } \\
\text { [Status] }\end{array}$ & Phase & $\mathbf{N}$ & Official Name & $\begin{array}{l}\text { Type of EC } \\
\text { Included }\end{array}$ & $\begin{array}{l}\text { Drugs and Treatment } \\
\text { Scheme }\end{array}$ & Radiation Regimen and Schedule & Primary Outcomes & Secondary Outcomes \\
\hline \multicolumn{9}{|c|}{ Recently completed clinical trials } \\
\hline $\begin{array}{l}\text { NCT00285415 } \\
\text { [Completed] }\end{array}$ & II & 46 & $\begin{array}{l}\text { A Phase II Evaluation of } \\
\text { Docetaxel and Carboplatin } \\
\text { Followed by Tumor } \\
\text { Volume Directed Pelvic } \\
\text { Plus or Minus Para-Aortic } \\
\text { Irradiation for Stage III/IV } \\
\text { Endometrial Carcinoma }\end{array}$ & $\begin{array}{l}\text { Advanced stage } \\
\text { III and } \\
\text { pelvis-confined } \\
\text { stage IV or } \\
\text { recurrent EC }\end{array}$ & $\begin{array}{c}\text { Docetaxel }+ \\
\text { carboplatin: every } 3 \\
\text { weeks for } 6 \text { cycles }\end{array}$ & $\begin{array}{c}\text { Tumor Volume Directed Pelvic } \pm \\
\text { Para-Aortic Irradiation. } \\
\text { After chemotherapy }\end{array}$ & ORR & $\begin{array}{l}\text { OS, PFS, safety } \\
\text { and tolerability }\end{array}$ \\
\hline \multicolumn{9}{|c|}{ Active clinical trials } \\
\hline $\begin{array}{l}\text { NCT03935256 } \\
\text { [Recruiting] }\end{array}$ & II & 24 & $\begin{array}{c}\text { Phase II Study of } \\
\text { Concurrent and Sequential } \\
\text { Carboplatin and Paclitaxel } \\
\text { With Adjuvant } \\
\text { Radiotherapy for High Risk } \\
\text { Endometrial Cancer }\end{array}$ & $\begin{array}{l}\text { Locally } \\
\text { advanced stage } \\
\text { III-IVA EC }\end{array}$ & $\begin{array}{c}\text { Carboplatin + } \\
\text { paclitaxel: } \\
\text { Arm 1: carboplatin + } \\
\text { paclitaxel } 4 \text { cycles } \\
\text { weeks 1, 10, } 13 \text { and } 16 . \\
\text { Arm 2: carboplatin }+ \\
\text { paclitaxel } 2 \text { cycles } \\
\text { weeks } 4 \text { and } 7+\text { RT }\end{array}$ & $\begin{array}{c}\text { EBPR of } 45 \text { Gy in } 25 \text { fractions } \\
\text { followed by vaginal BT boost at } \\
\text { doses of } 12-18 \text { Gy in } 2-3 \text { fractions. } \\
\text { Sequentially and concurrent with } \\
\text { carboplatin + paclitaxel }\end{array}$ & Acute toxicities & $\begin{array}{c}\text { Treatment delays, } \\
\text { chronic toxicities, } \\
\text { local control, pelvic } \\
\text { failure-free survival, } \\
\text { distant } \\
\text { metastasis-free } \\
\text { survival, } \\
\text { cause-specific } \\
\text { survival, DFS and OS }\end{array}$ \\
\hline $\begin{array}{c}\text { DeCRESCEndo } \\
\text { NCT04386993 } \\
\text { [Not yet } \\
\text { recruiting] }\end{array}$ & II & 25 & $\begin{array}{l}\text { De-escalated Conformal } \\
\text { Radiation Expedited } \\
\text { Sequentially With } \\
\text { Chemotherapy for } \\
\text { Endometrial Cancer } \\
\text { (DeCRESCEndo) }\end{array}$ & Stage III-IVA EC & $\begin{array}{l}\text { Chemotherapy: } \\
\text { regimen not } \\
\text { determined }\end{array}$ & $\begin{array}{l}\text { IMRT: 5-Gy in } 5 \text { fractions with } \\
\text { elective simultaneous boost to any } \\
\text { suspicious lymph node or residual } \\
\text { disease to } 30 \text { Gy in } 1-2 \text { weeks. } \\
\text { Sequentially with chemotherapy }\end{array}$ & $\begin{array}{l}\text { Adverse effects } \\
\text { incidence }\end{array}$ & $\begin{array}{c}\text { Change in } \\
\text { patient-reported } \\
\text { toxicity, change in } \\
\text { QOL, Loco-regional } \\
\text { control, distant } \\
\text { control, DFS and OS }\end{array}$ \\
\hline
\end{tabular}


Table 2. Cont.

\begin{tabular}{|c|c|c|c|c|c|c|c|c|}
\hline $\begin{array}{l}\text { PORTEC-3 } \\
\text { NCT00411138 } \\
\text { [Active, not } \\
\text { recruiting] }\end{array}$ & III & 670 & $\begin{array}{c}\text { Randomized Phase III Trial } \\
\text { Comparing Concurrent } \\
\text { Chemoradiation and } \\
\text { Adjuvant Chemotherapy } \\
\text { With Pelvic Radiation } \\
\text { Alone in High Risk and } \\
\text { Advanced Stage } \\
\text { Endometrial Carcinoma: } \\
\text { PORTEC-3 }\end{array}$ & $\begin{array}{c}\text { High risk stage } \\
\text { I-III EC }\end{array}$ & $\begin{array}{c}\text { Cisplatin + paclitaxel + } \\
\text { carboplatin: Arm 1: } \\
\text { EBPR combined with } 2 \\
\text { cycles of cisplatin } \\
\text { followed by } 4 \text { cycles of } \\
\text { carboplatin + paclitaxel } \\
\text { Am 2: ERBT and vaginal } \\
\text { BT in case of } \\
\text { cervical involvement }\end{array}$ & $\begin{array}{l}\text { EBPR: } 48.6 \text { Gy in } 1.8 \text { Gy } \\
\text { fractions up to } 6 \text { weeks and } \\
\text { vaginal BT boost in case of } \\
\text { cervical involvement. } \\
\text { Alone or concurrently } \\
\text { with chemotherapy }\end{array}$ & $\begin{array}{l}\text { OS, failure-free } \\
\text { survival }\end{array}$ & $\begin{array}{c}\text { QOL, severe } \\
\text { treatment-related } \\
\text { morbidity, vaginal or } \\
\text { pelvic relapse and } \\
\text { distant metastasis }\end{array}$ \\
\hline $\begin{array}{l}\text { NCT00942357 } \\
\text { [Active, not } \\
\text { recruiting] }\end{array}$ & III & 813 & $\begin{array}{l}\text { A Randomized Phase III } \\
\text { Trial of Cisplatin and } \\
\text { Tumor Volume Directed } \\
\text { Irradiation Followed by } \\
\text { Carboplatin and Paclitaxel } \\
\text { vs. Carboplatin and } \\
\text { Paclitaxel for Optimally } \\
\text { Debulked, Advanced } \\
\text { Endometrial Carcinoma }\end{array}$ & Stage I-IVA EC & $\begin{array}{c}\text { Carboplatin + paclitaxel } \\
\pm \text { cisplatin: } \\
\text { Arm 1: cisplatin + VDRT } \\
\text { or BT. After } \\
\text { chemoradiotherapy, } \\
\text { paclitaxel + carboplatin } \\
\text { Arm 2: } \\
\text { paclitaxel + carboplatin }\end{array}$ & $\begin{array}{l}\text { VDRT } 5 \text { days a week for } 5-6 \\
\text { weeks or BT over } 2-3 \text { weeks. } \\
\text { Concurrent with chemotherapy }\end{array}$ & $\begin{array}{l}\text { Number of } \\
\text { participants with } \\
\text { recurrence, } \\
\text { progression or death }\end{array}$ & $\begin{array}{c}\text { Number of participants } \\
\text { with acute late adverse } \\
\text { effects, OS, } \\
\text { patient-reported- } \\
\text { neuropathy symptoms } \\
\text { and QOL }\end{array}$ \\
\hline $\begin{array}{l}\text { NCT00807768 } \\
\text { [Active, not } \\
\text { recruiting] }\end{array}$ & III & 601 & $\begin{array}{c}\text { A Phase III Trial of Pelvic } \\
\text { Radiation Therapy Versus } \\
\text { Vaginal Cuff Brachytherapy } \\
\text { Followed by } \\
\text { Paclitaxel/Carboplatin } \\
\text { Chemotherapy in Patients } \\
\text { With High Risk, Early Stage } \\
\text { Endometrial Carcinoma }\end{array}$ & $\begin{array}{c}\text { High risk stage } \\
\text { I-II EC }\end{array}$ & $\begin{array}{l}\text { Carboplatin + paclitaxel: } \\
\text { Arm 1: IMRT } \pm \text { BT when } \\
\text { specified } \\
\text { Arm 2: BT + carboplatin } \\
\text { + paclitaxel }\end{array}$ & $\begin{array}{l}\text { IRMT: } 25-28 \text { fractions during } \\
5-6 \text { weeks. } \\
\text { BT: } 3-5 \text { high-dose rate } \\
\text { treatments over } 2 \text { weeks or } 1-2 \\
\text { low-dose rate over } 1-2 \text { days. } \\
\text { Chemotherapy given within } 3 \\
\text { weeks after initiating BT }\end{array}$ & $\begin{array}{l}\text { Number of } \\
\text { participants with } \\
\text { recurrence or death } \\
\text { events at } \\
\text { primary analysis }\end{array}$ & $\begin{array}{c}\text { Number of participants } \\
\text { with death events and } \\
\text { with sites of recurrence, } \\
\text { patient-reported fatigue } \\
\text { and neurotoxicity } \\
\text { and QOL }\end{array}$ \\
\hline $\begin{array}{l}\text { NCT00492778 } \\
\text { [recruiting] }\end{array}$ & II & 164 & $\begin{array}{l}\text { A Randomized Trial of } \\
\text { Pelvic Irradiation With or } \\
\text { Without Concurrent } \\
\text { Weekly Cisplatin in } \\
\text { Patients With Pelvic-Only } \\
\text { Recurrence of Carcinoma of } \\
\text { the Uterine Corpus }\end{array}$ & Recurrent EC & $\begin{array}{c}\text { Cisplatin: } \\
\text { Arm 1: EBRT followed by } \\
\text { intracavitary or } \\
\text { interstitial rate } \\
\text { interstitial BT } \\
\text { Arm 2: EBRT + cisplatin, } \\
\text { followed by BT }\end{array}$ & $\begin{array}{l}\text { EBRT on days } 1-5 \text { for } 5 \text { weeks. } \\
\text { Intracavitary low-dose or } \\
\text { high-dose rate BT or low-dose } \\
\text { rate interstitial BT. } \\
\text { Concurrently with } \\
\text { chemotherapy }\end{array}$ & PFS & $\begin{array}{l}\text { OS, Prognostic } \\
\text { significance of tumor } \\
\text { size, tumor location } \\
\text { (vaginal only vs. all } \\
\text { others) and histology } \\
\text { and incidence of } \\
\text { adverse effects }\end{array}$ \\
\hline
\end{tabular}

response rate; OS: overall survival; PFS: progression-free survival; QOL: quality of life; RT: radiotherapy; VDRT: volume-directed radiation therapy. 
Some studies have studied tolerability, efficacy and secondary effects of GF with RT. A phase II trial (NCT00545792) has assessed the anti-VEGF antibody bevacizumab with or without RT in recurrent pelvic-confined gynecological cancers, including EC. Results from this trial concluded that the delivery of bevacizumab with concurrent radiation provides excellent local tumor control and survival, particularly in those patients with unresectable nodes [61]. Later, another phase II trial (NCT01005329) investigated the administration of intensity-modulated radiation therapy (IMRT) in combination with bevacizumab and cisplatin, followed by carboplatin and cisplatin, for efficacy and secondary effects in patients who had undergone surgery for high-risk EC. Results from this clinical trial revealed that postoperative bevacizumab added to chemotherapy and pelvic IMRT appeared to be well tolerated and resulted in high OS rates after two years in patients with high-risk EC [61]. Finally, an older phase III clinical trial (NCT00033605) published in 2008 investigated the utility of octreotide, a somatostatin analog able to inhibit $\mathrm{GH}$, in reducing diarrhea in patients undergoing pelvic radiation as treatment of various cancers, including EC [121]. The authors concluded that octreotide not only did not decrease diarrhea but also worsened gastrointestinal symptoms in some patients. Thus, the administration of octreotide was not indicated, despite previous shown success in reducing severe liquid bowel content [122]. The clinical trial did not assess radiosensitization effects due to octreotide.

Regarding PARP inhibitors, an ongoing phase I trial (NCT03968406) is determining optimal drug dose, safety and tolerability of talazoparib in combination with RT in patients with gynecologic cancers, including EC that have relapsed after previous treatment. The trial aims to analyze incidence of side-effects, response rate, local control rate, time to progression, PFS, OS, level of PARP inhibition, $\mathrm{Y}-\mathrm{H} 2 \mathrm{AX}$ and RAD51 foci formation levels and overall quality of life, among other variables.

Immunotherapy constitutes a new paradigm of novel therapies with promising radiosensitizing properties. In 2003, a phase III trial (NCT00006011) started to analyze the effect of the immune system activators filgrastim and its pegylated version, pegfilgrastim, in combination with cisplatin, doxorubicin and \pm paclitaxel, in previously irradiated EC patients. Filgrastim induces the proliferation of neutrophil progenitor cells and it is used for the treatment of chemotherapy-induced neutropenia [123]. The investigators of the trial concluded that the addition of paclitaxel to cisplatin and doxorubicin following surgery and radiation was not associated with a significant improvement in recurrence-free survival but with increased toxicity [124]. More recently, novel proposed immunotherapies in combination with RT have just started to emerge for EC treatment. Currently, there are five clinical trials in recruitment status that aim to assess the efficacy, the maximum tolerated dose of the drug and side-effects of RT with immune checkpoint inhibitors, in particular monoclonal antibodies against PD-1, PD-L1 or CTLA-4. The first one is a phase II trial with pembrolizumab (anti-PD-1), vitamin $\mathrm{D}$, aspirin, cyclophosphamide, lansoprazole and curcumin administered concurrently with EBRT in advanced or refractory EC (PRIMMO, NCT03192059). This study aims to primarily determine overall response rate at week 26 . The second one is a phase I clinical trial using pembrolizumab administered before chemoradiation treatment (paclitaxel and carboplatin and, BT) in high and intermediate-risk EC patients (FIERCE, NCT03932409). This study intends to primarily determine the proportion of patients completing three cycles of pembrolizumab combined with dose dense paclitaxel and carboplatin chemotherapy during a time frame of 36 months. The third one is a phase III clinical trial testing pembrolizumab with EBRT and BT in stage I-II EC patients that are mismatch repair deficient. Pembrolizumab is administered seven days prior to RT. The primary outcome of the trial is to compare the three-year RFS of patients treated with RT plus pembrolizumab versus RT alone. The fourth one is a phase I clinical trial deploying durvalumab (anti-PD-L1) and tremelimumab (anti-CTLA-4) with concurrent EBRT in metastatic or unresectable ECs (NCT03277482). The primary outcome of this study consists of determining the maximum tolerated dose of RT with durvalumab and tremelimumab during a time frame of eight weeks as well as the incidence of dose-limiting toxicities for each dose level or regimen. Finally, the fifth one is a phase I clinical trial employing TSR-042 (anti-PD-1) administered before BT in inoperable stage I/II EC patients (NCT03955978). The primary outcome of the trial is to assess safety and tolerability of TSR-042 with BT measured by the grade of toxicities experienced by 
the patients during a time frame of six weeks. We expect the results of these four clinical trials to be reported in the near future.

Apart from the targeted therapies used in combination with RT, we have identified seven recently closed or currently active clinical trials employing chemotherapy plus RT in EC that are worth mentioning. The first is a phase II study (NCT00285415) completed in September 2019, which aimed to determine the effectiveness of the combination of carboplatin and docetaxel followed by tumor volume directed pelvic plus or minus para-aortic irradiation in stage III/IV or recurrent EC. Its primary objective was the estimation of the overall response rate of the therapy. The second is a phase II clinical trial (NCT03935256), which is evaluating the safety of sequential and concurrent carboplatin and paclitaxel with adjuvant EBRT for locally advanced EC. Its primary objective is to assess acute grade 3-4 non-hematologic and grade 4 hematologic toxicities associated with the above regimen. The third is a phase II study (NCT04386993), namely DeCRESCEndo, which will assess the benefit of short course radiation in post-operative stage III-IVA EC patients. The investigators hypothesize that short course pelvic radiation will benefit patients from both convenient and effective loco-regional control comparable to the traditional 5-6 weeks of radiation, and will have low acute and late grade 3-4 toxicity rate $(<10 \%)$. The fourth is the phase II trial (NCT00411138) including high-risk stage I-III EC patients, which intends to study the efficacy on the administration of chemotherapy and RT compared to RT alone. The fifth is a phase III trial (NCT00942357) that aimed to assess the efficacy of carboplatin and paclitaxel in with or without cisplatin and RT in stage I-IVA EC patients. Results from the trial revealed that chemotherapy plus RT was not associated with longer relapse-free survival compared to chemotherapy alone [13]. The sixth is a phase III trial (NCT00807768) including patients with high-risk stage I or stage II EC that has assessed the efficacy of pelvic RT compared to vaginal implant RT, paclitaxel and carboplatin. Results failed to demonstrate the superiority of vaginal RT compared with pelvic RT. In addition, although late toxicity was similar in both arms, acute toxicity was greater in the vaginal RT-treated one. Authors concluded that pelvic RT alone remains an effective, well-tolerated and appropriate adjuvant treatment in high-risk early-stage EC for all histologies [12]. Finally, the seventh study is a phase II trial (NCT00492778) that is evaluating the efficacy of RT and cisplatin compared to RT alone in patients with recurrent EC.

Taking into account all these observations, we think that there are two promising strategies in the horizon likely to be implemented in the clinic. On the one hand, there is a clear interest in investigating immune checkpoint inhibitors in combination with RT in EC; five out of the six active clinical trials employing targeted therapies are utilizing immunotherapies (Table 1). Although these clinical trials have not yet reported results, there is evidence that the strategy has worked in improving OS and PFS in metastatic disease of several cancers including EC [125]. On the other hand, we identified that the foremost recent studies with chemo- and RT in EC investigate modern variants of radiation therapy such as proton therapy, intensity-modulated radiation therapy (IMRT) and volume-modulated arc radiotherapy (VMAT), alone or in combination with platinum compounds (Table 2), with results yet to be published in most of the cases. Such modern therapies have the advantage of reducing off-target irradiations [126] and associated secondary effects in EC [127,128]. Moreover, IMRT and VMAT, alone or combined with chemotherapy, have successfully reduced the risks of recurrence and death in non-endometrioid EC. Patients over 60 years of age as well as those with endometrioid histology, lymphovascular space invasion, and with two or more positive lymph nodes benefitted the most [128].

\section{Cutting-Edge Advances in Radiotherapy for Endometrial Cancer}

The latest advances in RT and its closely related fields for EC encompasses several experimental approaches that include modern RT techniques and radiogenomics. 


\subsection{Modern Radiotherapy}

RT techniques used for EC treatment are divided into external or internal BT depending on the localization of the RT source. Modern external RT techniques that have emerged in the past few decades include IMRT, VMAT and stereotactic body radiation therapy. IMRT uses multiple x-rays beam of different intensities and angled from different directions with the objective to adapt better to the irregular shape of tumors. In EC, this type of RT prevents organs of the pelvic region such as the bladder and rectum to be excessively irradiated, decreasing related morbidities and side effects. This method is always used with image-guided RT (IGRT), which consists of the imaging of the tumor by computed tomography (CT) scan or x-rays and allows for a very precise targeting of the tumor in three dimensions (3D). One step forward is the addition of 4D in IGRT, which enables the adjustment of the beams in real-time during the treatment. Disadvantages of IMRT are the increased risk of secondary malignancies induced by the radiation and the longer time needed for delivering the radiation, which VMAT have tried to overcome [129]. VMAT, which was introduced in 2007, consists of the delivery of the radiation by a source that continuously rotates $360^{\circ}$. Both IMRT and VMAT have a good balance benefit/risk in EC compared to conventional conformal RT [129]. Like EBRT, BT has evolved into intensity-modulated BT (IMBT), 3D and 4D-IGBT, having the same promises and drawbacks as IMRT and IGRT [130]. Both 3D and 4D-IGBT have shown good local control for women with recurrent EC [131,132] and a 3D-EGBT high response rate in inoperable early stage endometrioid EC [133]. Finally, a novel RT emerging for the treatment of EC is proton therapy. Proton therapy uses protons that are accelerated by a synchrotron. The advantages are that it allows higher doses of radiation in the tumor while it reduces irradiation of nearby healthy tissues up to $60 \%$, which decreases secondary effects. Its use, however, is not as widely available in the hospitals as conventional RT. A clinical trial currently in recruiting status will assess toxicity as well as PFS and quality of life of proton therapy in 25 patients with uterine cervical and endometrial malignant neoplasms (NCT03184350). Patients will receive a fractionated dose of 45-50.4 Gy 5-6 times per week using an active raster-scanning pencil beam proton radiation.

\subsection{Radiogenomics}

Alongside the progress of genomic technology, radiogenomics has emerged as a novel discipline for the discovery of biomarkers for the prediction of RT response. The identification of such biomarkers is still in its infancy in EC. Currently, informed decisions about RT administration in EC are mainly based on clinical and histopathological characteristics that are unable to fully explain the RT responses. However, some works have brought light into the genes and mechanisms that determine EC sensitivity to RT. Yard et al. profiled 533 genetically annotated human cancer cell lines and identified genetic determinants of the response to radiation [21]. They found an association between radiation sensitivity and low copy number alterations, high frequency of mutations and mutations in DNA repair genes in EC cell lines [21]. Interestingly, most of the cell lines harboring mutations in the p85-binding domain of PIK3CA were sensitive to radiation and 38\% belonged to the uterine lineage. Additionally, a recent genomic stratification has helped the treatment decision in EC [5]. This study has revealed frequent incorrect IHC subtyping between high-grade type 1 and type 2 ECs; and also, inappropriate allocation of RT in endometrioid copy-number high ECs when they would better benefit from chemotherapy.

\section{Conclusions}

EC presents generally very good prognosis except in the $20 \%$ of cases, which metastasize or locally relapse. RT is the first-line treatment after surgery for EC in early stages and plays a crucial role reducing the risk of recurrences. The clinical importance of RT in EC is witnessed in the literature with numerous entries. However, despite being so widely used in this cancer, the basic knowledge about the cellular processes and individual biomarkers that determine sensitivity or resistance to RT is rather limited. Currently, there is some general consensus about the positive association 
between PI3K/AKT/mTOR, MAPK, NF- $\mathrm{BB}$, growth factor receptor and growth hormone activation and radioresistance; and between DNA repair machinery deficiencies and radiosensitivity in EC. Regarding the immune system, abrogation of both CTLA-4 and PD-1 pathways has been associated with greater radiosensitivity. Despite this existing knowledge, there is still a long way to go to fully understand the molecular determinants responsible for radiosensitivity in EC and whole-genome studies can be the perfect tool to unravel these unknowns. They have already provided extensive knowledge about the molecular characteristics in EC and a relatively recent subtyping scheme. In the future more sophisticated radiogenomics studies employing latest technologies, such as single-cell genomics, will allow the detection of dynamic changes during and after irradiation with associations between a positive RT response to gene and protein expression changes, which can be later targeted by highly selective therapeutic approaches. This will lay the foundation for personalized radiotherapy, which will improve treatment outcomes in EC.

Supplementary Materials: The following are available online at http://www.mdpi.com/2072-6694/12/7/1906/s1, Figure S1 Effects on overall survival and progression-free survival of mutations in the PTEN/PI3K/AKT pathway in endometrial cancer. Figure S2 Effects on overall survival and progression-free survival of mutations in the PTEN/PI3K/AKT pathway in endometrial cancer.

Author Contributions: A.S. was responsible of the conceptualization, writing, editing, supervision, project administration and funding; M.A.S. wrote Sections 2 and 4 and Section 3.7. E.P. wrote Sections 3.2, 3.3 and 3.6. All authors have read and agreed to the published version of the manuscript.

Funding: This research was funded by the Raine Medical Research Foundation (grant number: RPG-004-19) and by Cancer Council Western Australia Collaborative Cancer Funding Scheme (grant ID: 814) given to A.S., and by the 2018 project award from Merck Salud Foundation and the University and Research Grants Management Agency (AGAUR) of Catalonia Government (emergent research group recognition award (2017SRG1620) given to M.A.S.

Conflicts of Interest: The authors declare no conflict of interest. The funders had no role in the design of the study; in the collection, analyses or interpretation of data; in the writing of the manuscript, or in the decision to publish the results.

\section{References}

1. Ferlay, J.; Colombet, M.; Soerjomataram, I.; Mathers, C.; Parkin, D.M.; Pineros, M.; Znaor, A.; Bray, F. Estimating the global cancer incidence and mortality in 2018: GLOBOCAN sources and methods. Int. J. Cancer 2019, 144, 1941-1953. [CrossRef] [PubMed]

2. Group, A.E.S.; Blake, P.; Swart, A.M.; Orton, J.; Kitchener, H.; Whelan, T.; Lukka, H.; Eisenhauer, E.; Bacon, M.; $\mathrm{Tu}, \mathrm{D}$; ; et al. Adjuvant external beam radiotherapy in the treatment of endometrial cancer (MRC ASTEC and NCIC CTG EN.5 randomised trials): Pooled trial results, systematic review, and meta-analysis. Lancet 2009, 373, 137-146. [CrossRef]

3. Siegel, R.L.; Miller, K.D.; Jemal, A. Cancer statistics, 2020. CA Cancer J. Clin. 2020, 70, 7-30. [CrossRef] [PubMed]

4. Amant, F.; Moerman, P.; Neven, P.; Timmerman, D.; Van Limbergen, E.; Vergote, I. Endometrial cancer. Lancet 2005, 366, 491-505. [CrossRef]

5. Cancer Genome Atlas Research, N.; Kandoth, C.; Schultz, N.; Cherniack, A.D.; Akbani, R.; Liu, Y.; Shen, H.; Robertson, A.G.; Pashtan, I.; Shen, R.; et al. Integrated genomic characterization of endometrial carcinoma. Nature 2013, 497, 67-73. [CrossRef]

6. de Boer, S.M.; Powell, M.E.; Mileshkin, L.; Katsaros, D.; Bessette, P.; Haie-Meder, C.; Ottevanger, P.B.; Ledermann, J.A.; Khaw, P.; D’Amico, R.; et al. Adjuvant chemoradiotherapy versus radiotherapy alone in women with high-risk endometrial cancer (PORTEC-3): Patterns of recurrence and post-hoc survival analysis of a randomised phase 3 trial. Lancet Oncol. 2019, 20, 1273-1285. [CrossRef]

7. Geisler, H.E. The use of megestrol acetate in the treatment of advanced malignant lesions of the endometrium. Gynecol. Oncol. 1973, 1, 340-344. [CrossRef]

8. Makker, V.; Taylor, M.H.; Aghajanian, C.; Oaknin, A.; Mier, J.; Cohn, A.L.; Romeo, M.; Bratos, R.; Brose, M.S.; DiSimone, C.; et al. Lenvatinib Plus Pembrolizumab in Patients With Advanced Endometrial Cancer. J. Clin. Oncol. 2020. [CrossRef] 
9. Shepherd, J.H. Revised FIGO staging for gynaecological cancer. Br. J. Obs. Gynaecol. 1989, 96, 889-892. [CrossRef]

10. Pecorelli, S. Revised FIGO staging for carcinoma of the vulva, cervix, and endometrium. Int. J. Gynaecol. Obs. 2009, 105, 103-104. [CrossRef]

11. Colombo, N.; Creutzberg, C.; Amant, F.; Bosse, T.; Gonzalez-Martin, A.; Ledermann, J.; Marth, C.; Nout, R.; Querleu, D.; Mirza, M.R.; et al. ESMO-ESGO-ESTRO Consensus Conference on Endometrial Cancer: Diagnosis, treatment and follow-up. Ann. Oncol. 2016, 27, 16-41. [CrossRef] [PubMed]

12. Randall, M.E.; Filiaci, V.; McMeekin, D.S.; von Gruenigen, V.; Huang, H.; Yashar, C.M.; Mannel, R.S.; Kim, J.W.; Salani, R.; DiSilvestro, P.A.; et al. Phase III Trial: Adjuvant Pelvic Radiation Therapy Versus Vaginal Brachytherapy Plus Paclitaxel/Carboplatin in High-Intermediate and High-Risk Early Stage Endometrial Cancer. J. Clin. Oncol. 2019, 37, 1810-1818. [CrossRef] [PubMed]

13. Matei, D.; Filiaci, V.; Randall, M.E.; Mutch, D.; Steinhoff, M.M.; DiSilvestro, P.A.; Moxley, K.M.; Kim, Y.M.; Powell, M.A.; O'Malley, D.M.; et al. Adjuvant Chemotherapy plus Radiation for Locally Advanced Endometrial Cancer. N. Engl. J. Med. 2019, 380, 2317-2326. [CrossRef] [PubMed]

14. de Boer, S.M.; Powell, M.E.; Mileshkin, L.; Katsaros, D.; Bessette, P.; Haie-Meder, C.; Ottevanger, P.B.; Ledermann, J.A.; Khaw, P.; Colombo, A.; et al. Adjuvant chemoradiotherapy versus radiotherapy alone for women with high-risk endometrial cancer (PORTEC-3): Final results of an international, open-label, multicentre, randomised, phase 3 trial. Lancet Oncol. 2018, 19, 295-309. [CrossRef]

15. Risinger, J.I.; Hayes, K.; Maxwell, G.L.; Carney, M.E.; Dodge, R.K.; Barrett, J.C.; Berchuck, A. PTEN mutation in endometrial cancers is associated with favorable clinical and pathologic characteristics. Clin. Cancer Res. 1998, 4, 3005-3010.

16. Salvesen, H.B.; Carter, S.L.; Mannelqvist, M.; Dutt, A.; Getz, G.; Stefansson, I.M.; Raeder, M.B.; Sos, M.L.; Engelsen, I.B.; Trovik, J.; et al. Integrated genomic profiling of endometrial carcinoma associates aggressive tumors with indicators of PI3 kinase activation. Proc. Natl. Acad. Sci. USA 2009, 106, 4834-4839. [CrossRef]

17. Cheung, L.W.; Hennessy, B.T.; Li, J.; Yu, S.; Myers, A.P.; Djordjevic, B.; Lu, Y.; Stemke-Hale, K.; Dyer, M.D.; Zhang, F.; et al. High frequency of PIK3R1 and PIK3R2 mutations in endometrial cancer elucidates a novel mechanism for regulation of PTEN protein stability. Cancer Discov. 2011, 1, 170-185. [CrossRef]

18. Shoji, K.; Oda, K.; Nakagawa, S.; Hosokawa, S.; Nagae, G.; Uehara, Y.; Sone, K.; Miyamoto, Y.; Hiraike, H.; Hiraike-Wada, O.; et al. The oncogenic mutation in the pleckstrin homology domain of AKT1 in endometrial carcinomas. Br. J. Cancer 2009, 101, 145-148. [CrossRef]

19. Wang, E.; Sorolla, A. Sensitizing endometrial cancer to ionizing radiation by multi-tyrosine kinase inhibition. J. Gynaecol. Oncol. 2020, 31, e29. [CrossRef]

20. Miyasaka, A.; Oda, K.; Ikeda, Y.; Sone, K.; Fukuda, T.; Inaba, K.; Makii, C.; Enomoto, A.; Hosoya, N.; Tanikawa, M.; et al. PI3K/mTOR pathway inhibition overcomes radioresistance via suppression of the HIF1-alpha/VEGF pathway in endometrial cancer. Gynaecol. Oncol. 2015, 138, 174-180. [CrossRef]

21. Yard, B.D.; Adams, D.J.; Chie, E.K.; Tamayo, P.; Battaglia, J.S.; Gopal, P.; Rogacki, K.; Pearson, B.E.; Phillips, J.; Raymond, D.P.; et al. A genetic basis for the variation in the vulnerability of cancer to DNA damage. Nat. Commun. 2016, 7, 11428. [CrossRef] [PubMed]

22. Mukherjee, A.; Patterson, A.L.; George, J.W.; Carpenter, T.J.; Madaj, Z.B.; Hostetter, G.; Risinger, J.I.; Teixeira, J.M. Nuclear PTEN Localization Contributes to DNA Damage Response in Endometrial Adenocarcinoma and Could Have a Diagnostic Benefit for Therapeutic Management of the Disease. Mol. Cancer 2018, 17, 1995-2003. [CrossRef] [PubMed]

23. Saxton, R.A.; Sabatini, D.M. mTOR Signaling in Growth, Metabolism, and Disease. Cell 2017, 168, 960-976. [CrossRef] [PubMed]

24. Holst, F.; Werner, H.M.J.; Mjos, S.; Hoivik, E.A.; Kusonmano, K.; Wik, E.; Berg, A.; Birkeland, E.; Gibson, W.J.; Halle, M.K.; et al. PIK3CA Amplification Associates with Aggressive Phenotype but Not Markers of AKT-MTOR Signaling in Endometrial Carcinoma. Clin. Cancer Res. 2019, 25, 334-345. [CrossRef] [PubMed]

25. Kourea, H.P.; Nikolaou, M.; Tzelepi, V.; Adonakis, G.; Kardamakis, D.; Tsapanos, V.; Scopa, C.D.; Kalofonos, C.; Decavalas, G. Expression of phosphorylated Akt, mTOR and MAPK in type I endometrial carcinoma: Clinical significance. Anticancer Res. 2015, 35, 2321-2331.

26. Lin, D.I. Improved survival associated with somatic PIK3CA mutations in copy-number low endometrioid endometrial adenocarcinoma. Oncol. Lett. 2015, 10, 2743-2748. [CrossRef] 
27. McIntyre, J.B.; Nelson, G.S.; Ghatage, P.; Morris, D.; Duggan, M.A.; Lee, C.H.; Doll, C.M.; Köbel, M. PIK3CA missense mutation is associated with unfavorable outcome in grade 3 endometrioid carcinoma but not in serous endometrial carcinoma. Gynaecol. Oncol. 2014, 132, 188-193. [CrossRef]

28. Catasus, L.; Gallardo, A.; Cuatrecasas, M.; Prat, J. Concomitant PI3K-AKT and p53 alterations in endometrial carcinomas are associated with poor prognosis. Mod. Pathol. 2009, 22, 522-529. [CrossRef]

29. Jeck, W.; Roque, D.R.; Hayes, D.N.; Dizon, A.M.; Clark, L.H.; Pierce, S.; Wysham, W.Z.; Gehrig, P.A.; Bae-Jump, V.L. Frequency of multiple PIK3CA and PK3R1 concurrent mutations in endometrial cancers. J. Clin. Oncol. 2015, 33, e16522. [CrossRef]

30. Akiyama, A.; Minaguchi, T.; Fujieda, K.; Hosokawa, Y.; Nishida, K.; Shikama, A.; Tasaka, N.; Sakurai, M.; Ochi, H.; Satoh, T. Abnormal accumulation of p53 predicts radioresistance leading to poor survival in patients with endometrial carcinoma. Oncol. Lett. 2019, 18, 5952-5958. [CrossRef]

31. Cohen, Y.; Shalmon, B.; Korach, J.; Barshack, I.; Fridman, E.; Rechavi, G. AKT1 pleckstrin homology domain E17K activating mutation in endometrial carcinoma. Gynaecol. Oncol. 2010, 116, 88-91. [CrossRef] [PubMed]

32. Banno, K.; Yanokura, M.; Iida, M.; Masuda, K.; Aoki, D. Carcinogenic mechanisms of endometrial cancer: Involvement of genetics and epigenetics. J. Obs. Gynaecol. Res. 2014, 40, 1957-1967. [CrossRef] [PubMed]

33. Roberts, P.J.; Der, C.J. Targeting the Raf-MEK-ERK mitogen-activated protein kinase cascade for the treatment of cancer. Oncogene 2007, 26, 3291-3310. [CrossRef]

34. Aslan, O.; Cremona, M.; Morgan, C.; Cheung, L.W.; Mills, G.B.; Hennessy, B.T. Preclinical evaluation and reverse phase protein Array-based profiling of PI3K and MEK inhibitors in endometrial carcinoma in vitro. BMC Cancer 2018, 18, 168. [CrossRef] [PubMed]

35. Dent, P.; Yacoub, A.; Fisher, P.B.; Hagan, M.P.; Grant, S. MAPK pathways in radiation responses. Oncogene 2003, 22, 5885-5896. [CrossRef] [PubMed]

36. Marampon, F.; Gravina, G.L.; Popov, V.M.; Scarsella, L.; Festuccia, C.; La Verghetta, M.E.; Parente, S.; Cerasani, M.; Bruera, G.; Ficorella, C.; et al. Close correlation between MEK/ERK and Aurora-B signaling pathways in sustaining tumorigenic potential and radioresistance of gynecological cancer cell lines. Int. J. Oncol. 2014, 44, 285-294. [CrossRef]

37. Wang, E.; Sorolla, A.; Cunningham, P.T.; Bogdawa, H.M.; Beck, S.; Golden, E.; Dewhurst, R.E.; Florez, L.; Cruickshank, M.N.; Hoffmann, K.; et al. Tumor penetrating peptides inhibiting MYC as a potent targeted therapeutic strategy for triple-negative breast cancers. Oncogene 2019, 38, 140-150. [CrossRef]

38. Sorolla, A.; Wang, E.; Golden, E.; Duffy, C.; Henriques, S.T.; Redfern, A.D.; Blancafort, P. Precision medicine by designer interference peptides: Applications in oncology and molecular therapeutics. Oncogene 2020, 39, 1167-1184. [CrossRef]

39. Borst, M.P.; Baker, V.V.; Dixon, D.; Hatch, K.D.; Shingleton, H.M.; Miller, D.M. Oncogene alterations in endometrial carcinoma. Gynaecol. Oncol. 1990, 38, 364-366. [CrossRef]

40. Manning, G.; Tichy, A.; Sirak, I.; Badie, C. Radiotherapy-Associated Long-term Modification of Expression of the Inflammatory Biomarker Genes ARG1, BCL2L1, and MYC. Front. Immunol. 2017, 8, 412. [CrossRef]

41. Karin, M.; Ben-Neriah, Y. Phosphorylation meets ubiquitination: The control of NF-[kappa]B activity. Annu. Rev. Immunol. 2000, 18, 621-663. [CrossRef] [PubMed]

42. Karin, M.; Cao, Y.; Greten, F.R.; Li, Z.W. NF-kappaB in cancer: From innocent bystander to major culprit. Nat. Rev. Cancer 2002, 2, 301-310. [CrossRef]

43. Pallares, J.; Martinez-Guitarte, J.L.; Dolcet, X.; Llobet, D.; Rue, M.; Palacios, J.; Prat, J.; Matias-Guiu, X. Abnormalities in the NF-kappaB family and related proteins in endometrial carcinoma. J. Pathol. 2004, 204, 569-577. [CrossRef] [PubMed]

44. Aggarwal, B.B.; Sung, B. NF-kappaB in cancer: A matter of life and death. Cancer Discov. 2011, 1, 469-471. [CrossRef] [PubMed]

45. Santacana, M.; Yeramian, A.; Velasco, A.; Bergada, L.; Gatius, S.; Garcia, V.; Azueta, A.; Palacios, J.; Dolcet, X.; Oliva, E.; et al. Immunohistochemical features of post-radiation vaginal recurrences of endometrioid carcinomas of the endometrium: Role for proteins involved in resistance to apoptosis and hypoxia. Histopathology 2012, 60, 460-471. [CrossRef]

46. Baud, V.; Karin, M. Is NF-kappaB a good target for cancer therapy? Hopes and pitfalls. Nat. Rev. Drug Discov. 2009, 8, 33-40. [CrossRef]

47. Gray, L.H.; Conger, A.D.; Ebert, M.; Hornsey, S.; Scott, O.C. The concentration of oxygen dissolved in tissues at the time of irradiation as a factor in radiotherapy. Br. J. Radiol. 1953, 26, 638-648. [CrossRef] 
48. Overgaard, J.; Hansen, H.S.; Overgaard, M.; Bastholt, L.; Berthelsen, A.; Specht, L.; Lindeløv, B.; Jørgensen, K. A randomized double-blind phase III study of nimorazole as a hypoxic radiosensitizer of primary radiotherapy in supraglottic larynx and pharynx carcinoma. Results of the Danish Head and Neck Cancer Study (DAHANCA) Protocol 5-85. Radiother. Oncol. 1998, 46, 135-146. [CrossRef]

49. Koukourakis, M.I.; Giatromanolaki, A.; Sivridis, E.; Fezoulidis, I. Cancer vascularization: Implications in radiotherapy? Int. J. Radiat. Oncol. Biol. Phys. 2000, 48, 545-553. [CrossRef]

50. Sivridis, E.; Giatromanolaki, A.; Gatter, K.C.; Harris, A.L.; Koukourakis, M.I. Association of hypoxia-inducible factors 1alpha and 2alpha with activated angiogenic pathways and prognosis in patients with endometrial carcinoma. Cancer 2002, 95, 1055-1063. [CrossRef]

51. Rius, J.; Guma, M.; Schachtrup, C.; Akassoglou, K.; Zinkernagel, A.S.; Nizet, V.; Johnson, R.S.; Haddad, G.G.; Karin, M. NF-kappaB links innate immunity to the hypoxic response through transcriptional regulation of HIF-1alpha. Nature 2008, 453, 807-811. [CrossRef]

52. Yeramian, A.; Santacana, M.; Sorolla, A.; Llobet, D.; Encinas, M.; Velasco, A.; Bahi, N.; Eritja, N.; Domingo, M.; Oliva, E.; et al. Nuclear factor-kappaB2/p100 promotes endometrial carcinoma cell survival under hypoxia in a HIF-1alpha independent manner. Lab. Investig. 2011, 91, 859-871. [CrossRef]

53. Pijnenborg, J.M.; Wijnakker, M.; Hagelstein, J.; Delvoux, B.; Groothuis, P.G. Hypoxia contributes to development of recurrent endometrial carcinoma. Int. J. Gynaecol. Cancer 2007, 17, 897-904. [CrossRef]

54. Chakravarti, A.; Chakladar, A.; Delaney, M.A.; Latham, D.E.; Loeffler, J.S. The epidermal growth factor receptor pathway mediates resistance to sequential administration of radiation and chemotherapy in primary human glioblastoma cells in a RAS-dependent manner. Cancer Res. 2002, 62, 4307-4315. [PubMed]

55. Uzawa, K.; Ishigami, T.; Fushimi, K.; Kawata, T.; Shinozuka, K.; Kasamatsu, A.; Sakamoto, Y.; Ogawara, K.; Shiiba, M.; Bukawa, H.; et al. Targeting fibroblast growth factor receptor 3 enhances radiosensitivity in human squamous cancer cells. Oncogene 2011, 30, 4447-4452. [CrossRef] [PubMed]

56. Slomovitz, B.M.; Broaddus, R.R.; Schmandt, R.; Wu, W.; Oh, J.C.; Ramondetta, L.M.; Burke, T.W.; Gershenson, D.M.; Lu, K.H. Expression of imatinib mesylate-targeted kinases in endometrial carcinoma. Gynaecol. Oncol. 2004, 95, 32-36. [CrossRef] [PubMed]

57. Westin, S.N.; Broaddus, R.R. Personalized therapy in endometrial cancer: Challenges and opportunities. Cancer Biol. 2012, 13, 1-13. [CrossRef] [PubMed]

58. Shi, Y.; Liu, N.; Lai, W.; Yan, B.; Chen, L.; Liu, S.; Liu, S.; Wang, X.; Xiao, D.; Liu, X.; et al. Nuclear EGFR-PKM2 axis induces cancer stem cell-like characteristics in irradiation-resistant cells. Cancer Lett. 2018, 422, 81-93. [CrossRef] [PubMed]

59. Kim, S.M.; Rhee, Y.H.; Kim, J.S. The Anticancer Effects of Radachlorin-mediated Photodynamic Therapy in the Human Endometrial Adenocarcinoma Cell Line HEC-1-A. Anticancer Res. 2017, 37, 6251-6258. [CrossRef] [PubMed]

60. Koukourakis, M.I.; Limberis, V.; Tentes, I.; Kontomanolis, E.; Kortsaris, A.; Sivridis, E.; Giatromanolaki, A. Serum VEGF levels and tissue activation of VEGFR2/KDR receptors in patients with breast and gynecologic cancer. Cytokine 2011, 53, 370-375. [CrossRef] [PubMed]

61. Viswanathan, A.N.; Lee, H.; Berkowitz, R.; Berlin, S.; Campos, S.; Feltmate, C.; Horowitz, N.; Muto, M.; Sadow, C.A.; Matulonis, U. A prospective feasibility study of radiation and concurrent bevacizumab for recurrent endometrial cancer. Gynaecol. Oncol. 2014, 132, 55-60. [CrossRef] [PubMed]

62. Wu, Z.S.; Yang, K.; Wan, Y.; Qian, P.X.; Perry, J.K.; Chiesa, J.; Mertani, H.C.; Zhu, T.; Lobie, P.E. Tumor expression of human growth hormone and human prolactin predict a worse survival outcome in patients with mammary or endometrial carcinoma. J. Clin. Endocrinol. Metab. 2011, 96, E1619-E1629. [CrossRef] [PubMed]

63. Pandey, V.; Perry, J.K.; Mohankumar, K.M.; Kong, X.J.; Liu, S.M.; Wu, Z.S.; Mitchell, M.D.; Zhu, T.; Lobie, P.E. Autocrine human growth hormone stimulates oncogenicity of endometrial carcinoma cells. Endocrinology 2008, 149, 3909-3919. [CrossRef] [PubMed]

64. Bougen, N.M.; Yang, T.; Chen, H.; Lobie, P.E.; Perry, J.K. Autocrine human growth hormone reduces mammary and endometrial carcinoma cell sensitivity to mitomycin C. Oncol. Rep. 2011, 26, 487-493. [CrossRef]

65. Bougen, N.M.; Steiner, M.; Pertziger, M.; Banerjee, A.; Brunet-Dunand, S.E.; Zhu, T.; Lobie, P.E.; Perry, J.K. Autocrine human GH promotes radioresistance in mammary and endometrial carcinoma cells. Endocr. Relat. Cancer 2012, 19, 625-644. [CrossRef] 
66. Evans, A.; Jamieson, S.M.; Liu, D.X.; Wilson, W.R.; Perry, J.K. Growth hormone receptor antagonism suppresses tumour regrowth after radiotherapy in an endometrial cancer xenograft model. Cancer Lett. 2016, 379, 117-123. [CrossRef]

67. Rantanen, V.; Grenman, S.; Kulmala, J.; Alanen, K.; Lakkala, T.; Grenman, R. Sublethal damage repair after fractionated irradiation in endometrial cancer cell lines tested with the 96-well plate clonogenic assay. J. Cancer Res. Clin. Oncol. 1994, 120, 712-716. [CrossRef]

68. Biau, J.; Chautard, E.; Verrelle, P.; Dutreix, M. Altering DNA Repair to Improve Radiation Therapy: Specific and Multiple Pathway Targeting. Front. Oncol. 2019, 9, 1009. [CrossRef]

69. Awasthi, P.; Foiani, M.; Kumar, A. ATM and ATR signaling at a glance. J. Cell Sci. 2016, 129, 1285. [CrossRef]

70. Teng, P.N.; Bateman, N.W.; Darcy, K.M.; Hamilton, C.A.; Maxwell, G.L.; Bakkenist, C.J.; Conrads, T.P. Pharmacologic inhibition of ATR and ATM offers clinically important distinctions to enhancing platinum or radiation response in ovarian, endometrial, and cervical cancer cells. Gynaecol. Oncol. 2015, 136, 554-561. [CrossRef]

71. Takeuchi, M.; Tanikawa, M.; Nagasaka, K.; Oda, K.; Kawata, Y.; Oki, S.; Agapiti, C.; Sone, K.; Miyagawa, Y.; Hiraike, H.; et al. Anti-Tumor Effect of Inhibition of DNA Damage Response Proteins, ATM and ATR, in Endometrial Cancer Cells. Cancers 2019, 11, 1913. [CrossRef]

72. de Jonge, M.M.; Auguste, A.; van Wijk, L.M.; Schouten, P.C.; Meijers, M.; Ter Haar, N.T.; Smit, V.; Nout, R.A.; Glaire, M.A.; Church, D.N.; et al. Frequent Homologous Recombination Deficiency in High-grade Endometrial Carcinomas. Clin. Cancer Res. 2019, 25, 1087-1097. [CrossRef] [PubMed]

73. Arvanitis, D.A.; Angelakis, E.; Koumantakis, E.E.; Spandidos, D.A. Allelic imbalance in hMLH1 or BRCA2 loci associated with response of cervical and endometrial cancer to radiotherapy. Int. J. Mol. Med. 2002, 10, 55-63. [CrossRef] [PubMed]

74. Reijnen, C.; Kusters-Vandevelde, H.V.N.; Prinsen, C.F.; Massuger, L.; Snijders, M.; Kommoss, S.; Brucker, S.Y.; Kwon, J.S.; McAlpine, J.N.; Pijnenborg, J.M.A. Mismatch repair deficiency as a predictive marker for response to adjuvant radiotherapy in endometrial cancer. Gynaecol. Oncol. 2019, 154, 124-130. [CrossRef] [PubMed]

75. Smith, G.C.; Jackson, S.P. The DNA-dependent protein kinase. Genes Dev. 1999, 13, 916-934. [CrossRef]

76. Saygili, U.; Gorkay, I.B.; Koyuncuoglu, M.; Gol, M.; Uslu, T.; Erten, O. The relationship between expression of Ku70 and survival in irradiated patients with endometrial carcinoma. Gynaecol. Oncol. 2004, 95, 518-522. [CrossRef]

77. Toufektchan, E.; Toledo, F. The Guardian of the Genome Revisited: p53 Downregulates Genes Required for Telomere Maintenance, DNA Repair, and Centromere Structure. Cancers 2018, 10, 135. [CrossRef]

78. Rantanen, V.; Grenman, S.; Kurvinen, K.; Hietanen, S.; Raitanen, M.; Syrjanen, S. p53 mutations and presence of HPV DNA do not correlate with radiosensitivity of gynecological cancer cell lines. Gynaecol. Oncol. 1998, 71, 352-358. [CrossRef]

79. Saffari, B.; Bernstein, L.; Hong, D.C.; Sullivan-Halley, J.; Runnebaum, I.B.; Grill, H.J.; Jones, L.A.; El-Naggar, A.; Press, M.F. Association of p53 mutations and a codon 72 single nucleotide polymorphism with lower overall survival and responsiveness to adjuvant radiotherapy in endometrioid endometrial carcinomas. Int. J. Gynaecol. Cancer 2005, 15, 952-963. [CrossRef]

80. Mandeville, R.; Sidrac-Ghali, S.; Ajdukovic, I.; Vidal, D.; Ayoub, J. Early inhibition of natural and interferon-activated killers in endometrial cancer patients treated with local radiotherapy. Cancer Detect. Prev. 1987, 10, 129-139.

81. Son, C.H.; Fleming, G.F.; Moroney, J.W. Potential role of radiation therapy in augmenting the activity of immunotherapy for gynecologic cancers. Cancer Manag. Res. 2017, 9, 553-563. [CrossRef] [PubMed]

82. Frenel, J.-S.; Tourneau, C.L.; O’Neil, B.H.; Ott, P.A.; Piha-Paul, S.A.; Gomez-Roca, C.A.; Brummelen, E.V.; Rugo, H.S.; Thomas, S.; Saraf, S.; et al. Pembrolizumab in patients with advanced cervical squamous cell cancer: Preliminary results from the phase Ib KEYNOTE-028 study. J. Clin. Oncol. 2016, 34, 5515. [CrossRef]

83. Ott, P.A.; Bang, Y.-J.; Berton-Rigaud, D.; Elez, E.; Pishvaian, M.J.; Rugo, H.S.; Puzanov, I.; Morgan, M.A.; Mehnert, J.M.; Aung, K.L.; et al. Pembrolizumab in advanced endometrial cancer: Preliminary results from the phase Ib KEYNOTE-028 study. J. Clin. Oncol. 2016, 34, 5581. [CrossRef]

84. Le, D.T.; Uram, J.N.; Wang, H.; Bartlett, B.R.; Kemberling, H.; Eyring, A.D.; Skora, A.D.; Luber, B.S.; Azad, N.S.; Laheru, D.; et al. PD-1 Blockade in Tumors with Mismatch-Repair Deficiency. N. Engl. J. Med. 2015, 372, 2509-2520. [CrossRef] 
85. Howitt, B.E.; Shukla, S.A.; Sholl, L.M.; Ritterhouse, L.L.; Watkins, J.C.; Rodig, S.; Stover, E.; Strickland, K.C.; D'Andrea, A.D.; Wu, C.J.; et al. Association of Polymerase e-Mutated and Microsatellite-Instable Endometrial Cancers With Neoantigen Load, Number of Tumor-Infiltrating Lymphocytes, and Expression of PD-1 and PD-L1. JAMA Oncol. 2015, 1, 1319-1323. [CrossRef]

86. Lee, L.; Matulonis, U. Immunotherapy and radiation combinatorial trials in gynecologic cancer: A potential synergy? Gynaecol. Oncol. 2019, 154, 236-245. [CrossRef]

87. Dovedi, S.J.; Adlard, A.L.; Lipowska-Bhalla, G.; McKenna, C.; Jones, S.; Cheadle, E.J.; Stratford, I.J.; Poon, E.; Morrow, M.; Stewart, R.; et al. Acquired resistance to fractionated radiotherapy can be overcome by concurrent PD-L1 blockade. Cancer Res. 2014, 74, 5458-5468. [CrossRef]

88. Lin, L.L.; Lakomy, D.S.; Ning, M.S.; Simpkins, F.; Jhingran, A. Combining novel agents with radiotherapy for gynecologic malignancies: Beyond the era of cisplatin. Int. J. Gynaecol. Cancer 2020, 30, 409-423. [CrossRef]

89. Salehi, F.; Scheithauer, B.W.; Sharma, S.; Kovacs, K.; Lloyd, R.V.; Cusimano, M.D.; Munoz, D.G. Immunohistochemical expression of PTTG in brain tumors. Anticancer Res. 2013, 33, 119-122.

90. Zhang, X.; Horwitz, G.A.; Heaney, A.P.; Nakashima, M.; Prezant, T.R.; Bronstein, M.D.; Melmed, S. Pituitary tumor transforming gene (PTTG) expression in pituitary adenomas. J. Clin. Endocrinol. Metab. 1999, 84, 761-767. [CrossRef]

91. Zhang, S.X.; Shan, W.X.; Yuan, L.P.; Liu, Y.L.; Sun, L.Z. Effects of silencing PTTG expression by small interference RNA. Eur. Rev. Med. Pharm. Sci. 2016, 20, 2835-2841.

92. Murphy, M.E. The HSP70 family and cancer. Carcinogenesis 2013, 34, 1181-1188. [CrossRef]

93. Du, X.L.; Jiang, T.; Wen, Z.Q.; Gao, R.; Cui, M.; Wang, F. Silencing of heat shock protein 70 expression enhances radiotherapy efficacy and inhibits cell invasion in endometrial cancer cell line. Croat. Med. J. 2009, 50, 143-150. [CrossRef]

94. Gao, Q.; Huang, X.; Tang, D.; Cao, Y.; Chen, G.; Lu, Y.; Zhuang, L.; Wang, S.; Xu, G.; Zhou, J.; et al. Influence of chk1 and plk1 silencing on radiation- or cisplatin-induced cytotoxicity in human malignant cells. Apoptosis 2006, 11, 1789-1800. [CrossRef] [PubMed]

95. Ye, F.; Yang, Z.; Liu, Y.; Gong, D.; Ji, T.; Wang, J.; Xi, B.; Zhou, J.; Ma, D.; Gao, Q. Co-abrogation of Chk1 and Chk2 by potent oncolytic adenovirus potentiates the antitumor efficacy of cisplatin or irradiation. Cancer Gene 2014, 21, 209-217. [CrossRef]

96. Brown, L.F.; Berse, B.; Van de Water, L.; Papadopoulos-Sergiou, A.; Perruzzi, C.A.; Manseau, E.J.; Dvorak, H.F.; Senger, D.R. Expression and distribution of osteopontin in human tissues: Widespread association with luminal epithelial surfaces. Mol. Biol. Cell 1992, 3, 1169-1180. [CrossRef]

97. Chang, S.H.; Minai-Tehrani, A.; Shin, J.Y.; Park, S.; Kim, J.E.; Yu, K.N.; Hong, S.H.; Hong, C.M.; Lee, K.H.; Beck, G.R., Jr.; et al. Beclin1-induced autophagy abrogates radioresistance of lung cancer cells by suppressing osteopontin. J. Radiat. Res. 2012, 53, 422-432. [CrossRef]

98. Yang, L.; Zhao, W.; Zuo, W.S.; Wei, L.; Song, X.R.; Wang, X.W.; Zheng, G.; Zheng, M.Z. Silencing of osteopontin promotes the radiosensitivity of breast cancer cells by reducing the expression of hypoxia inducible factor 1 and vascular endothelial growth factor. Chin. Med. J. (Engl.) 2012, 125, $293-299$.

99. Hahne, J.C.; Meyer, S.R.; Kranke, P.; Dietl, J.; Guckenberger, M.; Polat, B.; Honig, A. Studies on the role of osteopontin-1 in endometrial cancer cell lines. Strahlenther. Onkol. 2013, 189, 1040-1048. [CrossRef]

100. Overgaard, J.; Eriksen, J.G.; Nordsmark, M.; Alsner, J.; Horsman, M.R.; Danish, H.; Neck Cancer Study, G. Plasma osteopontin, hypoxia, and response to the hypoxia sensitiser nimorazole in radiotherapy of head and neck cancer: Results from the DAHANCA 5 randomised double-blind placebo-controlled trial. Lancet Oncol. 2005, 6, 757-764. [CrossRef]

101. Singhal, H.; Bautista, D.S.; Tonkin, K.S.; O'Malley, F.P.; Tuck, A.B.; Chambers, A.F.; Harris, J.F. Elevated plasma osteopontin in metastatic breast cancer associated with increased tumor burden and decreased survival. Clin. Cancer Res. 1997, 3, 605-611. [PubMed]

102. Fujimoto, J.; Sakaguchi, H.; Aoki, I.; Tamaya, T. Steroid receptors and metastatic potential in endometrial cancers. Eur. J. Cancer 2000, 36 (Suppl. 4), S33. [CrossRef]

103. Jongen, V.; Briet, J.; de Jong, R.; ten Hoor, K.; Boezen, M.; van der Zee, A.; Nijman, H.; Hollema, H. Expression $\mathrm{o}-$ alpha and -beta and progesterone receptor-A and -B in a large cohort of patients with endometrioid endometrial cancer. Gynaecol. Oncol. 2009, 112, 537-542. [CrossRef] [PubMed]

104. Huber, H.; Husslein, P.; Michalica, W.; Wagenbichler, P. Radiosensitizing effect of medroxyprogesterone acetate on endometrial cancer cells in vitro. Cancer 1984, 54, 999-1001. [CrossRef] 
105. You, J.; Chen, W.; Chen, J.; Zheng, Q.; Dong, J.; Zhu, Y. The Oncogenic Role of ARG1 in Progression and Metastasis of Hepatocellular Carcinoma. Biomed. Res. Int. 2018, 2018, 2109865. [CrossRef]

106. Waghray, D.; Zhang, Q. Inhibit or Evade Multidrug Resistance P-Glycoprotein in Cancer Treatment. J. Med. Chem. 2018, 61, 5108-5121. [CrossRef]

107. Terek, M.C.; Zekioglu, O.; Sendag, F.; Akercan, F.; Ozsaran, A.; Erhan, Y. MDR1 gene expression in endometrial carcinoma. Int. J. Gynaecol. Cancer 2003, 13, 673-677. [CrossRef]

108. Wenz, F.; Engling, A.; Fruehauf, S.; Weber, K.J. Transfection of Human Cell Lines with the Human Multi-Drug-Resistence (MDR-1) Gene Suppresses Radiation-Induced Apoptosis and Increases Radioresistance. In Proceedings of the 43rd Annual ASTRO Meeting, San Francisco, CA, USA, 4-8 November 2001; p. 229.

109. Rosa, R.; D’Amato, V.; De Placido, S.; Bianco, R. Approaches for targeting cancer stem cells drug resistance. Expert Opin. Drug Discov. 2016, 11, 1201-1212. [CrossRef]

110. Baumann, M.; Krause, M.; Hill, R. Exploring the role of cancer stem cells in radioresistance. Nat. Rev. Cancer 2008, 8, 545-554. [CrossRef]

111. Giannone, G.; Attademo, L.; Scotto, G.; Genta, S.; Ghisoni, E.; Tuninetti, V.; Aglietta, M.; Pignata, S.; Valabrega, G. Endometrial Cancer Stem Cells: Role, Characterization and Therapeutic Implications. Cancers 2019, 11, 1820. [CrossRef]

112. Dong, P.; Konno, Y.; Watari, H.; Hosaka, M.; Noguchi, M.; Sakuragi, N. The impact of microRNA-mediated PI3K/AKT signaling on epithelial-mesenchymal transition and cancer stemness in endometrial cancer. J. Transl. Med. 2014, 12, 231. [CrossRef] [PubMed]

113. Franken, N.A.; Rodermond, H.M.; Stap, J.; Haveman, J.; van Bree, C. Clonogenic assay of cells in vitro. Nat. Protoc. 2006, 1, 2315-2319. [CrossRef] [PubMed]

114. Streffer, C.; Müller, W.-U.; Wuttke, K. The Formation of Micronuclei after Exposure to Ionizing Radiation. In Chromosomal Alterations; Obe, G., Natarajan, A.T., Eds.; Springer: Berlin/Heidelberg, Germany, 1994. [CrossRef]

115. Countryman, P.I.; Heddle, J.A. The production of micronuclei from chromosome aberrations in irradiated cultures of human lymphocytes. Mutat. Res. 1976, 41, 321-332. [CrossRef]

116. Habash, M.; Bohorquez, L.C.; Kyriakou, E.; Kron, T.; Martin, O.A.; Blyth, B.J. Clinical and Functional Assays of Radiosensitivity and Radiation-Induced Second Cancer. Cancers 2017, 9, 147. [CrossRef] [PubMed]

117. Emons, G.; Vordermark, D. Adjuvant treatment for endometrial cancer. Curr. Opin. Oncol. 2019, 31, 404-410. [CrossRef] [PubMed]

118. Gomez-Raposo, C.; Merino Salvador, M.; Aguayo Zamora, C.; Casado Saenz, E. Adjuvant chemotherapy in endometrial cancer. Cancer Chemother. Pharm. 2020, 85, 477-486. [CrossRef]

119. Kunos, C.A.; Sherertz, T.M.; Mislmani, M.; Ellis, R.J.; Lo, S.S.; Waggoner, S.E.; Zanotti, K.M.; Herrmann, K.; Debernardo, R.L. Phase I Trial of Carboplatin and Gemcitabine Chemotherapy and Stereotactic Ablative Radiosurgery for the Palliative Treatment of Persistent or Recurrent Gynecologic Cancer. Front. Oncol. 2015, 5, 126. [CrossRef]

120. Grigsby, P.W.; Graham, M.V.; Perez, C.A.; Galakatos, A.E.; Camel, H.M.; Kao, M.S. Prospective phase I/II studies of definitive irradiation and chemotherapy for advanced gynecologic malignancies. Am. J. Clin. Oncol. 1996, 19, 1-6. [CrossRef]

121. Martenson, J.A.; Halyard, M.Y.; Sloan, J.A.; Proulx, G.M.; Miller, R.C.; Deming, R.L.; Dick, S.J.; Johnson, H.A.; Tai, T.H.; Zhu, A.W.; et al. Phase III, double-blind study of depot octreotide versus placebo in the prevention of acute diarrhea in patients receiving pelvic radiation therapy: Results of North Central Cancer Treatment Group N00CA. J. Clin. Oncol. 2008, 26, 5248-5253. [CrossRef]

122. Maton, P.N.; O’Dorisio, T.M.; Howe, B.A.; McArthur, K.E.; Howard, J.M.; Cherner, J.A.; Malarkey, T.B.; Collen, M.J.; Gardner, J.D.; Jensen, R.T. Effect of a long-acting somatostatin analogue (SMS 201-995) in a patient with pancreatic cholera. N. Engl. J. Med. 1985, 312, 17-21. [CrossRef]

123. Kaczmarski, R.S.; Mufti, G.J. Low-dose filgrastim therapy for chronic neutropenia. N. Engl. J. Med. 1993, 329, 1280-1281. [CrossRef]

124. Homesley, H.D.; Filiaci, V.; Gibbons, S.K.; Long, H.J.; Cella, D.; Spirtos, N.M.; Morris, R.T.; DeGeest, K.; Lee, R.; Montag, A. A randomized phase III trial in advanced endometrial carcinoma of surgery and volume directed radiation followed by cisplatin and doxorubicin with or without paclitaxel: A Gynecologic Oncology Group study. Gynaecol. Oncol. 2009, 112, 543-552. [CrossRef] [PubMed] 
125. Luke, J.J.; Lemons, J.M.; Karrison, T.G.; Pitroda, S.P.; Melotek, J.M.; Zha, Y.; Al-Hallaq, H.A.; Arina, A.; Khodarev, N.N.; Janisch, L.; et al. Safety and Clinical Activity of Pembrolizumab and Multisite Stereotactic Body Radiotherapy in Patients with Advanced Solid Tumors. J. Clin. Oncol. 2018, 36, 1611-1618. [CrossRef]

126. Kandula, S.; Zhu, X.; Garden, A.S.; Gillin, M.; Rosenthal, D.I.; Ang, K.K.; Mohan, R.; Amin, M.V.; Garcia, J.A.; $\mathrm{Wu}, \mathrm{R}$;; et al. Spot-scanning beam proton therapy vs intensity-modulated radiation therapy for ipsilateral head and neck malignancies: A treatment planning comparison. Med. Dosim. 2013, 38, 390-394. [CrossRef]

127. Temelli, O.; Demirtas, M.; Sisecioglu, M.S.; Pepele, E.K. Dosimetric Comparison of Adjuvant Pelvic Radiotherapy for Endometrial Cancer using Intensity-Modulated Radiotherapy (IMRT), Volumetric Modulated Arc Therapy (VMAT) and Helical Tomotherapy (HT). Eurasian J. Med. Oncol. 2019, 3, 203-210. [CrossRef]

128. Chen, J.L.-Y.; Huang, Y.-S.; Huang, C.-Y.; Hsu, C.-Y.; Lan, K.-H.; Cheng, W.-F.; Kuo, S.-H. Impact of adjuvant radiotherapy on the survival of women with optimally resected stage III endometrial cancer in the era of modern radiotherapy: A retrospective study. Radiat. Oncol. 2020, 15, 72. [CrossRef] [PubMed]

129. Teoh, M.; Clark, C.H.; Wood, K.; Whitaker, S.; Nisbet, A. Volumetric modulated arc therapy: A review of current literature and clinical use in practice. Br. J. Radiol. 2011, 84, 967-996. [CrossRef] [PubMed]

130. Callaghan, C.M.; Adams, Q.; Flynn, R.T.; Wu, X.; Xu, W.; Kim, Y. Systematic Review of Intensity-Modulated Brachytherapy (IMBT): Static and Dynamic Techniques. Int. J. Radiat. Oncol. Biol. Phys. 2019, 105, $206-221$. [CrossRef]

131. Lee, L.J.; Damato, A.L.; Viswanathan, A.N. Clinical outcomes following 3D image-guided brachytherapy for vaginal recurrence of endometrial cancer. Gynaecol. Oncol. 2013, 131, 586-592. [CrossRef]

132. Fokdal, L.; Ortoft, G.; Hansen, E.S.; Rohl, L.; Pedersen, E.M.; Tanderup, K.; Lindegaard, J.C. Toward four-dimensional image-guided adaptive brachytherapy in locally recurrent endometrial cancer. Brachytherapy 2014, 13, 554-561. [CrossRef]

133. Jordan, S.E.; Micaily, I.; Hernandez, E.; Ferriss, J.S.; Miyamoto, C.T.; Li, S.; Micaily, B. Image-guided high-dose-rate intracavitary brachytherapy in the treatment of medically inoperable early-stage endometrioid type endometrial adenocarcinoma. Brachytherapy 2017, 16, 1144-1151. [CrossRef] [PubMed]

(C) 2020 by the authors. Licensee MDPI, Basel, Switzerland. This article is an open access article distributed under the terms and conditions of the Creative Commons Attribution (CC BY) license (http://creativecommons.org/licenses/by/4.0/). 